\title{
Treating Metastatic Brain Cancers With Stem Cells
}

\author{
Nadia Sadanandan ${ }^{1 \dagger}$, Alex Shear ${ }^{2 t}$, Beverly Brooks ${ }^{3 \dagger}$, Madeline Saft ${ }^{4}$, \\ Dorothy Anne Galang Cabantan ${ }^{5}$, Chase Kingsbury ${ }^{3}$, Henry Zhang ${ }^{2}$, Stefan Anthony, \\ Zhen-Jie Wang ${ }^{3}$, Felipe Esparza Salazar ${ }^{7}$, Alma R. Lezama Toledo', \\ Germán Rivera Monroy ${ }^{7}$, Joaquin Vega Gonzales-Portillo ${ }^{8}$, Alexa Moscatello ${ }^{3}$, \\ Jea-Young Lee ${ }^{3}$ and Cesario V. Borlongan ${ }^{3,9 *}$

\begin{abstract}
${ }^{1}$ Georgetown University, Washington, DC, United States, ${ }^{2}$ University of Florida, Gainesville, FL, United States, ${ }^{3}$ Department of Neurosurgery and Brain Repair, University of South Florida Morsani College of Medicine, Tampa, FL, United States, ${ }^{4}$ University of Michigan, Ann Arbor, MI, United States, ${ }^{5}$ Michigan State University College of Osteopathic Medicine, East Lansing, MI, United States, ${ }^{6}$ Lake Erie College of Osteopathic Medicine, Bradenton, FL, United States, ${ }^{7}$ Centro de Investigación en Ciencias de la Salud (CICSA), Facultad de Ciencias de la Salud (FCS), Universidad Anáhuac México Campus Norte, Huixquilucan, Mexico, ${ }^{8}$ Universidad Peruana de Ciencias Aplicadas, Lima, Peru, ${ }^{9}$ Center of Excellence for Aging and Brain Repair, University of South Florida Morsani College of Medicine, Tampa, FL, United States
\end{abstract}

\section{OPEN ACCESS}

Edited by:

Liliana Simões Mendonça, University of Coimbra, Portugal

Reviewed by: Claudia C. Faria,

Universidade de Lisboa, Portugal Baptiste Lacoste, Ottawa Hospital Research Institute (OHRI), Canada

*Correspondence: Cesario V. Borlongan cborlong@usf.edu

tThese authors have contributed equally to this work

Specialty section:

This article was submitted to Brain Disease Mechanisms, a section of the journal Frontiers in Molecular Neuroscience

Received: 29 July 2021 Accepted: 20 October 2021 Published: 24 November 2021

Citation:

Sadanandan N, Shear A, Brooks B, Saft M, Cabantan DAG, Kingsbury $C$, Zhang $H$, Anthony S, Wang Z-J, Salazar FE, Lezama Toledo AR, Rivera Monroy G, Vega Gonzales-Portillo J,

Moscatello A, Lee J-Y and Borlongan CV (2021) Treating Metastatic Brain Cancers With Stem
Stem cell therapy may present an effective treatment for metastatic brain cancer and glioblastoma. Here we posit the critical role of a leaky blood-brain barrier (BBB) as a key element for the development of brain metastases, specifically melanoma. By reviewing the immunological and inflammatory responses associated with BBB damage secondary to tumoral activity, we identify the involvement of this pathological process in the growth and formation of metastatic brain cancers. Likewise, we evaluate the hypothesis of regenerating impaired endothelial cells of the BBB and alleviating the damaged neurovascular unit to attenuate brain metastasis, using the endothelial progenitor cell (EPC) phenotype of bone marrow-derived mesenchymal stem cells. Specifically, there is a need to evaluate the efficacy for stem cell therapy to repair disruptions in the BBB and reduce inflammation in the brain, thereby causing attenuation of metastatic brain cancers. To establish the viability of stem cell therapy for the prevention and treatment of metastatic brain tumors, it is crucial to demonstrate BBB repair through augmentation of vasculogenesis and angiogenesis. BBB disruption is strongly linked to metastatic melanoma, worsens neuroinflammation during metastasis, and negatively influences the prognosis of metastatic brain cancer. Using stem cell therapy to interrupt inflammation secondary to this leaky BBB represents a paradigmshifting approach for brain cancer treatment. In this review article, we critically assess the advantages and disadvantages of using stem cell therapy for brain metastases and glioblastoma.

Keywords: blood brain barrier, melanoma, brain metastases, stem cell therapy, bone marrow derived mesenchymal stem cell, endothelial progenitor cell, neuroinflammation

\section{INTRODUCTION}

Limited evidence exists on treatments aimed at repairing the blood-brain barrier (BBB) in metastatic brain cancers. According to 2015 data, worldwide cases of melanoma were 351, 880 with Australasia, North America, Eastern Europe, Central Europe, and Western Europe having the highest incidences (Karimkhani et al., 2017). In the U.S, metastatic cancers account for 
$98,000-170,000$ of mass lesions in the brain, which amounts to $24-45 \%$ of all cancer patients and $20 \%$ of cancer deaths each year (Eisen et al., 2011; Patel et al., 2011; Schwartzentruber et al., 2011; Tu et al., 2011; Zhang et al., 2011; Kaneko et al., 2015; Kotecha et al., 2018; Valiente et al., 2018; Boire et al., 2020). Melanoma is a cancer of the skin with significant morbidity and mortality due to how it readily metastasizes to other areas of the body (e.g., brain) (Kaneko et al., 2015; Schadendorf et al., 2018; Simard et al., 2018; Turner et al., 2018; Gowda et al., 2020). Exploring mechanisms mediating melanoma metastasis advances the basic science understanding of tumor formation and opens avenues for developing novel treatments, including stem cell therapy for brain cancer (Rambow et al., 2018; Wickremesekera et al., 2019; Krishna et al., 2020; Kudchadkar et al., 2020; Zhu et al., 2020). Treating melanoma represents a significant unmet clinical need, as half a million Americans are diagnosed with melanoma each year. Novel strategies, such as stem cell therapy, for treating this melanoma, therefore, deserves serious investigation. Temporary injury to the BBB can allow systemic diseases to seize the opportunity to invade the central nervous system (CNS) (Gerstner and Fine, 2007; Fidler et al., 2010; Fidler, 2011; Sweeney et al., 2019; Profaci et al., 2020) leaving the brain susceptible to further tumor growth (Aragon-Ching and Zujewski, 2007; Palmieri et al., 2007; Kaneko et al., 2015; Osswald et al., 2016; Carmen-Orozco et al., 2019; Schulz et al., 2019; Yang and Torbey, 2020; Huang et al., 2021). An altered permeability in the leaky BBB allows pro-inflammatory molecules to enter the CNS, which may mediate the amelioration of the BBB can potentially decrease pro-tumorigenic effects (Toyoda et al., 2013; Varatharaj and Galea, 2017; Sarkaria et al., 2018; Kwon et al., 2019; Arvanitis et al., 2020).

Invasion of melanoma into the brain correlates with $\mathrm{BBB}$ impairment, which leads to the infiltration of inflammatory factors from systemic circulation and a subsequent increase in the malignancy of such cancers. Identifying that this neuroinflammation worsens malignancy, we hypothesize that through angiogenesis, stem cell therapy will repair the leaky $\mathrm{BBB}$, suppress inflammation, and ultimately decrease tumor growth and malignancy in the brain (Kaneko et al., 2015). Our proposal is that stem cell transplantation will hinder brain metastasis of melanoma through repair of the $\mathrm{BBB}$ and inhibition of brain inflammation. Of note, there are concerns regarding the use of stem cells and promoting angiogenesis or vasculogenesis in any form of cancer (Ramjiawan et al., 2017; Li S. et al., 2019; Atiya et al., 2020; Unterleuthner et al., 2020). Potentially, stem cells can support tumor growth, provide support for tumors, or become cancerous themselves (Ayob and Ramasamy, 2018; Chae and Kim, 2018; Volarevic et al., 2018; Vakhshiteh et al., 2019; Cable et al., 2020). The cell proliferative process of angiogenesis or vasculogenesis is traditionally viewed as an exacerbating factor for the formation of metastatic cancers; however, our proposition represents a paradigm shift in this perception (Kaneko et al., 2015; Batle and Clevers, 2017; López-Lázaro, 2018; Schito, 2019; Yi et al., 2019; Dzobo et al., 2020; Lv et al., 2020). As BBB breakdown is exacerbated by decreased angiogenesis and vasculogenesis, promotion of blood vessel growth through bone marrow-derived endothelial progenitor cells (EPCs) may rescue the BBB's function and attenuate developing brain metastases of melanoma. This hypothesis represents a significant advance over current data on the therapy and pathology of brain cancers (Kaneko et al., 2015; Yang J. et al., 2020).

Angiogenesis, vasculogenesis, and $\mathrm{BBB}$ genesis are all distinct phenomena, but are physiologically linked. In cerebrovascular development, blood vessel generation is directed by vasculogenesis and angiogenesis, which are discrete mechanisms (Lee et al., 2009; Yang J. et al., 2020). During development, vasculogenesis generates the primary vascular plexus, which is further developed into a highly intricate vascular network by angiogenesis (Yang J. et al., 2020). Vasculogenesis functions to generate new blood vessels but does so by inducing differentiation of endothelial cell precursors (angioblasts) into mature endothelial cells (Liman and Endres, 2012). Vascular damage triggers vasculogenesis in which bone marrow derived EPCs are stimulated and migrate to the injured site where they mature into endothelial cells (Liman and Endres, 2012). Moreover, damage to the $\mathrm{BBB}$ would provoke vasculogenesis with the aim to repair injured endothelial cells of the $\mathrm{BBB}$, thereby mitigating BBB disruption.

Angiogenesis is the process of new capillary formation from existing blood vessels (Rust, 2020). Angiogenesis assists in poststroke recovery, as the formation of new vessels is crucial for neurogenesis and synaptogenesis (Yang et al., 2018, 2013; 2018). After an ischemic stroke, angiogenesis is initiated in the periinfarct areas, which has been associated with improved stroke rehabilitation in preclinical models (Nih et al., 2018; Rust et al., 2019; Rust, 2020). Specifically, hypoxia induces endothelial cell damage, triggering the secretion of angiogenic factors, which promotes endothelial cell proliferation for the creation of new blood vessels (Schreiber et al., 2013; Yang et al., 2018; Yang J. et al., 2020). In response to inflammation, mesenchymal stromal cells (MSCs) promote angiogenic and trophic factors that repair and remodel the BBB (Zhang et al., 2020). Pericytes and endothelial cells associated with the $\mathrm{BBB}$ influence angiogenesis via secretion of angiogenic and trophic factors (Zhang et al., 2020). With the protection of pericytes, the endothelial cells can promote the generation of pericytes, which in turn can promote the stimulation of newly formed blood vessels and repair of endothelial tight junctions (Zhang et al., 2020). Increased permeability in the presence of inflammation is also influenced by astrocytes withdrawing endfeet interaction with vessels (Park et al., 2015). MSCs may have the ability to increase filaments in the astrocytic endfeet, which may restore interaction with blood vessels and cause the endfeet to extend back (Park et al., 2015). Astrocyte uptake of proinflammatory cytokine may be decreased in the presence of MSCs, thus strengthening the endothelium tight junctions via VEGF-A signaling (Park et al., 2015). These factors together have the potential to repair the leaky BBB while decreasing inflammation. Furthermore, both angiogenesis and vasculogenesis lead to formation of new blood vessels in response to vascular injury but proceed via different mechanisms.

Like vasculogenesis and angiogenesis, barriergenesis is an important component of cerebrovascular development. After 
angiogenesis completes the formation of the primary vascular network, barriergenesis occurs where cerebral vessels mature into the $\mathrm{BBB}$. This process is specifically mediated by mural cells and the formation of the extracellular matrix (ECM) (Lee et al., 2009; Al Ahmad et al., 2011; Yang J. et al., 2020). As the cerebrovasculature develops, the vessels interact with neurons and glial cells to compose the neurovascular unit (NVU). The crosstalk among endothelial cells, basement membrane, mural cells (e.g., pericytes), neurons, microglia, astrocytes, and oligodendrocytes, all of which function as the NVU, mediate angiogenesis and contribute to barriergenesis (Huang et al., 2020). These interactions among the components of the NVU indicate the link between angiogenesis and barriergenesis. There are signaling pathways, such as Wnt/beta-catenin, in the CNS that induce angiogenesis and also maintain the BBB, specifically upregulating the expression of tight junctions, transporters, and reinforcing $\mathrm{BBB}$ permeability (Blanchette and Daneman, 2015; Nguyen et al., 2021). Notably, Wnt/beta-catenin signaling seems to link angiogenesis and $\mathrm{BBB}$ maintenance, as the inhibition of this pathway spurs the dysregulation of angiogenesis and BBB impairment (Liebner et al., 2008; Blanchette and Daneman, 2015). In addition, TNF receptors, DR6 and TROY, are expressed in endothelial cells of the brain due Wnt stimulation and mediate barriergenesis and angiogenesis (Tam et al., 2012). Altogether, angiogenesis and vasculogenesis stand as similar mechanisms in the production of new blood vessels, both of which are important for cerebrovascular development and also repair of vascular injury, including BBB damage.

Using angiogenesis and vasculogenesis to repair $\mathrm{BBB}$ dysfunction and suppress metastatic brain disease is a controversial hypothesis. As with every other cell type in the body, cancer cells require vasculature for oxygen, nutrients, and removal of waste (Kaneko et al., 2015; Schaaf et al., 2018; Ma et al., 2019; Ballabio and Bonifacino, 2020; Ngoi et al., 2020). As tumors expand, their metabolic demand increases as well, leading to the production of pro-angiogenic factors (Folkman, 1990; Díaz-Flores et al., 1994; Zhang et al., 2012; Becerra and Notario, 2013; Rahma and Hodi, 2019; Ribatti and Tamma, 2019; Teleanu et al., 2019; Vaupel et al., 2019; Tasdogan et al., 2020; Testa et al., 2020). The vasculature associated with a tumor is poorly structured and functionally incompetent due to the disordered and rapid growth triggered by tumor cells, demonstrating an important caveat (Korfel et al., 2002; Graham and Unger, 2018; Petrillo et al., 2018; Zanotelli and Reinhart-King, 2018; Lugano et al., 2020). Often, these hastily constructed vessels are unable to support dependent tissue and lead to microenvironmental hypoxia and ischemia (Jain, 2005; Heath and Bicknell, 2009; Finger and Giaccia, 2010; von Loga and Gerlinger, 2017; Wang et al., 2018; Hinshaw and Shevde, 2019; Boedtkjer and Pedersen, 2020; Lugano et al., 2020; Wang C. et al., 2020). Continuing to inhibit angiogenesis and vasculogenesis exacerbates the damaging microenvironment, preventing repair of the damaged $\mathrm{BBB}$, and ultimately encouraging the pathological growth and formation of melanoma and other metastatic brain cancers (Finger and Giaccia, 2010; Luo et al., 2014; Da Ros et al., 2018; Liebner et al., 2018; Almeida et al., 2019; Gutzmer et al., 2020; Simiczyjew et al., 2020). Repairing the BBB by inducing the processes of angiogenesis and vasculogenesis holds promise as an effective intervention for attenuating brain metastatic cancer development.

\section{INFLAMMATION-MEDIATED BREACH OF BLOOD-BRAIN BARRIER IN BRAIN CANCER}

The BBB is a structure composed of capillary endothelial cells sealed with tight junctions and supported by the neurovascular unit, which consists of not only the endothelial cells but also pericytes, astrocytes, the extracellular matrix, neurons, and microglia (Persidsky et al., 2006; Daneman and Prat, 2015; Eldahshan et al., 2019; Langen et al., 2019). The BBB exhibits selective permeability due to tight junctions between endothelial cells and limited transcytosis due to the expression of selective transporters allowing for the regulation of ion and nutrient passage into the brain (Dejana, 2004; Abbott et al., 2006; Ayloo and Gu, 2019; Segarra et al., 2021). The structural features of the BBB correlate with its function to shield the brain from toxic substances and pathogens and preserve a state of homeostasis in the brain (Langen et al., 2019). The BBB also plays a role in mediating inflammation (Varatharaj and Galea, 2017) and nutrient supply (Dejana, 2004; Abbott et al., 2006; Segarra et al., 2021). The presence of brain tumors impairs BBB functionality and enhances permeability, especially at the location of the tumor (Groothuis et al., 1991; Deeken and Loscher, 2007; Molotkov et al., 2021). Metastatic brain tumors impair BBB functionality by breaking down tight junctions and inducing damage to the NVU, specifically astrocytes and pericytes.

Metastatic tumor cells may infiltrate the $\mathrm{BBB}$ in order to overwhelm the brain's functional tissue. To accomplish this, primary and metastatic brain tumor cells disrupt the structure and utility of the BBB by downregulating tight junction protein expression in endothelial cells, which leads to leakage (Liebner et al., 2000; Papadopoulos et al., 2001; Tran et al., 2019). Tumor cells may also upregulate the expression of proteases, such as cathepsin $\mathrm{S}$, which function to break down adhesion proteins in the BBB (Sevenich et al., 2014; Schulz et al., 2019). In addition, tumor cells diminish BBB functionality by impairing astrocytes and pericytes, which act as key regulators of BBB integrity (Daneman et al., 2010; Arvanitis et al., 2020). Astrocytes function by formulating plasmin upon leakage to combat metastatic invasion (Priego et al., 2018). An in vivo administration of the astrocyte toxin 3-chloropropanediol demonstrates how the repopulation of astrocytes in a damaged brain tissue can significantly reduce the fluorescent $10-\mathrm{kDa}$ dextran permeability utilized to portray leakage (Willis et al., 2004; Winkler et al., 2021). Moreover, pericytes regulate the BBB via endothelial cell gene expression, contractile fibers restricting capillary blood flow and transendothelial vesicular transport (Herndon et al., 2017). For example, a lack of pericytes in the endothelium downregulates CD71 (transferrin receptor) expression (Armulik et al., 2010; Herndon et al., 2017). Pericytes can also influence endothelial vesicular trafficking by suppressing Plvap which can affect transcytosis since Plvap is a gene highly expressed during BBB breakdown (Daneman et al., 2010; Wei et al., 2021). Consequently, leukocyte infiltration, edema, and neuronal 
degeneration result following astrocyte loss, and damaged pericytes compromise astrocytic endfeet polarization and vesicle trafficking (Bush et al., 1999; Armulik et al., 2010; Daneman et al., 2010). Glioma growth and invasion displace pericytes and astrocytic endfeet, damage endothelial cell tight junctions, and alter cell signaling (Dubois et al., 2014; Watkins et al., 2014; Arvanitis et al., 2020). Metastatic brain cells communicate with astrocytes via gap junctions, leading to astrocytic cytokine release that supports tumor progression, chemoresistance, and further BBB breakdown (Chen Q. et al., 2016; Liebner et al., 2018). Through interleukin 1-Beta-mediated NF-kB signaling, these metastatic cells can drive the transformation of healthy astrocytes into tumor associated astrocytes (TAAs) that foster tumor expansion (Xing et al., 2016). Once metastatic cancer cells overwhelm the $\mathrm{BBB}$, the structure develops into a highly variable blood-tumor barrier (BTB), which exhibits various levels of permeability (Babak et al., 2020).

When BBB functionality declines, tumor cells can more easily infiltrate the brain due to decreased selective permeability. High levels of tumor growth create hypoxic areas in the brain due to increased rates of oxygen consumption by tumor cells (Brown and Giaccia, 1998). The hypoxic tumor environment then plays a role in diminishing antitumor immune activity, specifically by suppressing T-cell and Natural killer cell responses (Hatfield et al., 2015; Rankin et al., 2016). On the other hand, hypoxia also generates a heightened inflammatory response that can enhance tumor growth (Finger and Giaccia, 2010; Guo et al., 2016; Salmaninejad et al., 2019). The hypoxic microenvironment from rapid and unregulated tumor growth then recruits macrophages (Finger and Giaccia, 2010; Guo et al., 2016) that release multiple angiogenic factors, including VEGF, which aid tumor extravasation and vascular permeability (Salmaninejad et al., 2019). VEGF and TGF $\beta 1 /$ Smad may interact together to increase angiogenesis in tumor growth, promoted by MSCs (Li et al., 2016). Interestingly, up to $50 \%$ of the tumor cells in a glioblastoma mass consist of tumor-associated macrophages, which encompass peripheral macrophages and microglia (Chen et al., 2017). In mice models of glioblastoma, blood levels of monocytes and neutrophils decreased substantially as the tumor progressed, indicating escalated infiltration of these immune cells across the BBB and into the tumor (Chen et al., 2017). Furthermore, macrophage migration to the tumor site seems to exacerbate brain metastases by fostering tumor growth rather than inhibiting it.

Additionally, brain metastatic cells secrete inflammatory cytokines, which recruit peripheral immune cells (e.g., macrophages, neutrophils, lymphocytes), leading to further tumorigenesis and metastasis (Finger and Giaccia, 2010; Xing et al., 2016). Notably, pro-inflammatory cytokines alone can significantly increase BBB permeability (Xiong et al., 2015; Molotkov et al., 2021), which would allow for further tumor cell infiltration into the brain and heightened neuroinflammation. In addition to promoting the proliferation of cells, inflammatory cytokines alter tumor-suppressor gene and oncogene expression, resulting in the attenuation of apoptotic mechanisms (Schetter et al., 2010; Saito et al., 2011; D’Orazi et al., 2021). Specifically, interleukin-6 (IL-6) has been associated with tumor growth and angiogenesis (Sansone et al., 2007; Iliopoulos et al., 2009; Korkaya et al., 2012; Chiou et al., 2013; Li S. et al., 2019). IL-6 has been shown to spur glioblastoma progression via the suppression of miR142-3p expression (Chiou et al., 2013). In patients with brain metastatic lung carcinoma, programmed death-ligand 1 (PD-L1) expressing myeloid cells were significantly higher in count compared to the healthy patients, and increased PD-L1 cell levels were correlated with worse patient outcome (Li Y. D. et al., 2019). Notably, anti-IL-6 antibodies diminished PD-L1 expression, indicating that IL-6 plays a role in the PD-L1induced immunosuppression associated with tumor expansion (Li et al., 2015). In addition, tumor necrosis factor alpha (TNF-a) has been shown to promote glioma progression via the TNIP1mediated TNF-a/NF-kB signaling pathway (Lei et al., 2020). Altogether, inflammatory cytokines released by brain metastatic cells and recruited macrophages bolster tumor cell proliferation, vascularization, and BBB leakiness, all of which led to further tumor expansion.

Given the role of the $\mathrm{BBB}$ in tumor growth and brain metastasis, restoration of the damaged $\mathrm{BBB}$ may serve as a promising therapeutic strategy against metastatic cancer. Amelioration of transcellular BBB leakiness could inhibit the infiltration of additional brain metastatic cells and invading peripheral immune cells, such as inflammatory macrophages. As a result, further tumor expansion and neuroinflammation could be mitigated by chemotherapy with increased BBB permeability presenting as a conducing brain microenvironment, as therapeutic molecules would have less difficulty entering the brain. However, multiple studies indicate that there is no correlation between tumor-induced BBB leakiness and increased efficacy of chemotherapeutic molecules (Rosner et al., 1986; Lee et al., 1989; Fujita et al., 2000; Bernardo et al., 2002; Chen et al., 2002; Korfel et al., 2002; Nisticò et al., 2012; Iwadate, 2016; Ashrafizadeh et al., 2020; Lin et al., 2020). Importantly, the efficacy of therapeutic delivery to the cancer-afflicted brain can be improved upon, potentially through nanoparticles (Ni et al., 2021), high-intensity focused ultrasound (HIFU) (Molotkov et al., 2021), or exosomes (Dong, 2018).

\section{STEM CELL RESCUE OF THE PATHOLOGIC BLOOD-BRAIN BARRIER}

Transplanted bone marrow-derived EPC, specifically modified to target angiogenic and vasculogenic pathways, may prove to be efficacious for BBB repair. Bone marrow-derived stem cells expressing EPC phenotypes, have previously been shown to ameliorate $\mathrm{BBB}$ damage and exhibit typical permeability while simultaneously preserving mitochondria and modulating pinocytosis in stroke, as also seen in amyotrophic lateral sclerosis (Borlongan et al., 2004; Garbuzova-Davis et al., 2017, 2018, 2019a,b, 2020; Eve et al., 2018; Saft et al., 2020). Similarly, this method could also be used to restore a leaky BBB observed in metastatic cancers.

Brain metastases can cause BBB breakdown allowing systemic circulating inflammatory mediators to bypass the $\mathrm{BBB}$ resulting in increased metastatic brain cancer 
proliferation (Sprowls et al., 2019; Arvanitis et al., 2020; Garbuzova-Davis and Borlongan, 2021). To illustrate this mechanism, experimental modeling of brain metastatic cancer, such as melanoma, has been executed by infusing into a common inbred strain mouse the mouse melanoma cell line B16F10 via intracarotid injection. Additionally, assessing brain tumor growth, BBB leakiness, and inflammatory response has been achieved through endpoint assays such as in situ hybridization, quantitative real-time polymerase chain reaction, and immunoreactive analyses. Considering that this leaky BBB-mediated inflammation worsens metastatic brain cancer outcomes (Bhowmik et al., 2015; Babak et al., 2020; Curtaz et al., 2020; Garbuzova-Davis and Borlongan, 2021), it is suggested that stem cell therapy will ameliorate $\mathrm{BBB}$ damage via angiogenesis, reduce brain inflammation, and decrease brain tumor growth rate. Current research indicates that bone marrow-derived MSCs can ameliorate the effects of a compromised BBB (Menge et al., 2012; Silva et al., 2020; Tang et al., 2020), providing a protective effect by decreasing BBB permeability (Menge et al., 2012; Ge et al., 2019; Lin et al., 2019; Wang C. et al., 2020) and selectively localize to solid tumor foci in multiple organs after intravenous administration (Metz et al., 2013; Gutova et al., 2016; Yang M. et al., 2020). The compromised BBB permeability reduction is due in part to an increase in the collagen IV expression, providing the framework for endothelial-endothelial cell interaction, and an increase in occludin, promoting paracellular tight junction formation within the endothelial layer (Wang et al., 2015). TIMP1/CD63 axis promotes hNSC movement via the FAK/PI3K signaling and activation of integrin signaling via binding of CD63/integrin $\beta 1$ complex, which in turn destabilizes the endothelial layer via inhibition of RhoA (Tang et al., 2020). MSCs produce TIMP3, a soluble factor which may inhibit VEGF-A, thus inhibiting further BBB breakdown (Menge et al., 2012). Furthermore, MSCs promote the up-regulation of Claudin-5, a tight junction protein essential to maintaining endothelial tight junctions, and increase MMP-9 levels resulting in restored BBB integrity in rat models (Lin et al., 2019). Stem cells combined with prodrug-activating enzymes can further induce the localization of a solid tumor formation, which may allow for tumor-localized chemotherapy (Metz et al., 2013). Furthermore, co-culture with hNSC decreases growth of brain metastasis from various cancers, decreases tumor volume and significantly prolongs survival (Seol et al., 2011; Hong et al., 2013; Mooney et al., 2021). BBB disruption caused by tumor progression exposes ECM substrates, which may cause hNSC attraction and localization, while anti-adhesive proteoglycans may protect undisturbed BBB (Mooney et al., 2021). NSC carrying therapeutic suicide genes, such as CE and CD, target tumor sites to activate chemotherapy drugs and induce cell death (Seol et al., 2011). Therapeutic use of allogenic human bone marrow-derived NSCs transfected with interferon- $\beta$ (IFN- $\beta$ ) diminishes tumor growth, decreases metastasis, and increases longevity via AKT and ERK1/2 phosphorylation in the tumor cells (Bao et al., 2012; Hagenhoff et al., 2016; Romero-Trejo et al., 2021). Combination therapy of IFN- $\beta$ /MSCs advantageously does not require immunosuppression and directly controls melanoma proliferation, allowing it to function as an anti-tumor therapy (Studeny et al., 2002; Du et al., 2019; Heo et al., 2019;
Serakinci and Cagsin, 2019; Serhal et al., 2019). In the presence of tumors, MSCs possess the ability to proliferate due to the increase in paracrine growth factors that are present in the tumor microenvironment, but compete with local mesenchymal precursors (Studeny et al., 2002; Wang J. X. et al., 2020). IFN- $\beta$ MSCs produce a direct anti-proliferative and metastatic effects on tumor cells by suppressing the cell proliferation gene expression and time-dependent mesenchymal-epithelial transition (MET) inhibition, respectively (Du et al., 2019; Heo et al., 2019). First, to demonstrate efficacy, direct implantation into an experimentally induced focal metastatic brain tumor may be required before evaluating an optimal route of SC transplantation. Afterward, using minimally invasive administration, such as intravenous (IV) or intra-arterial (IA), can portray the clinical expression identified by extensive infiltration on the majority of metastasized brain tumors. In terms of cell dosage, IA injections typically utilize lower doses of MSCs to effectively locate the metastatic cells. On the other hand, IV administration requires higher doses of MSCs to distribute over a wider area in a faster manner (Kabat et al., 2020; Rady et al., 2020). Additionally, the timing of implantation (e.g., acute vs. delayed metastasis) is critical to enhance clinical efficacy (Byun et al., 2020). When angiogenic genes are engineered into MSCs, especially if they have EPC phenotype, their transplantation serves as a viable treatment for attenuating brain inflammation and repairing the BBB (Antonucci et al., 2011; Miloradovic et al., 2020; Pawitan et al., 2020; Castelli et al., 2021; Li et al., 2021). For example, MSCs with overexpression of IL-10 shift macrophage expression from pro-inflammatory cytokines TNF-a and a reduction of activated macrophage and astrocytes correlated with a decrease in CD163 cells at the injury site in TBI models (Peruzzaro et al., 2019). MSC-EVs likewise reduced active astrocytes and microglial density in white matter following brain inflammation (Drommelschmidt et al., 2017). BMSCs with increased IL-12 influenced cell death by natural killer cell infiltration, arresting some cell growth in brain tumors (Hong et al., 2009). Moreover, establishing the therapeutic window for stem cell transplantation in brain metastasis should include evaluation of $\mathrm{BBB}$ repair and of decreased brain inflammation in both the acute and delayed injection time points of the mouse melanoma cell line B16F10. Along with the previously discussed endpoint assays (Zhang et al., 2018; Rady et al., 2020; Andrzejewska et al., 2021), and assessing the results of the grafted stem cells, we can outline the therapeutic potency of the stem cell transplants along with its safety in the brain. Potential advantages of cell therapy include the promotion of localized $\mathrm{BBB}$ angiogenesis and permeability, while reducing brain metastasis via anti-inflammatory processes. Additionally, optimizing timing and dose of stem cell transplant depending on their route of administration will allow safe and effective regimen in clinical trials for combatting melanoma derived brain metastatic brain cancer.

Due to the novelty of stem cell therapy to treat cancer, there are still many apprehensions of the effectiveness of this kind of treatment. Transplanted stem cells could possibly provide alternative angiogenic pathways for tumor growth and even become cancerous cells themselves (Razmkhah et al., 2019; Ahn, 2020; Atiya et al., 2020; Zhou et al., 2021). Thus, in order 
to advance stem cell-based treatments, rigorous examinations should delineate stem cell-induced BBB reconstruction from any adverse effects of inducing angiogenesis in cancerous brain cells, thereby localizing enhanced $\mathrm{BBB}$ permeability while mitigating tumor growth (Palmieri et al., 2007; Zhang et al., 2015; Le Rhun et al., 2019; Brighi et al., 2020; Hass et al., 2020; Lah et al., 2020; Yang M. et al., 2020).

\section{CAVEATS FOR COMBINING STEM CELL THERAPY WITH CHEMOTHERAPY}

Stem cell therapy has great success in the treatment of some cancers (Pascucci et al., 2014; Hu et al., 2018) and holds hope for other successful therapies as an adjunctive treatment (Chu et al., 2020). The effectiveness of cytotoxic therapy, such as in chemotherapy, may be restricted without the aid of other reagents (Lytle et al., 2021). The frequent use of HSC transplantation following high-dose chemotherapy (Copelan, 2006; Porfyriou et al., 2021) questions whether the treatment of stem cell therapy combined with chemotherapy may enhance therapeutics with heightened tumor targeting and elimination (Chu et al., 2020). However, when stem cell therapy is used in combination with chemotherapy for the treatment of cancer, this combination treatment can present contraindications and adverse events. Contradictory evidence exists on the long-term effectiveness of these combination therapies in some cancers as well (Table 1). These adverse events can present as stem cell contamination and toxicity, among others. Inflammation- and angiogenesis-relevant associated pathways can contribute to these challenges as well.

\section{Evaluation of the Treatment of Breast Cancer With the Combination of Chemotherapy and Stem Cell Therapies}

There is no conclusive data on high dose chemotherapy and stem cell long term benefits compared to standard therapy (Chen B. B. et al., 2016; Steenbruggen et al., 2020). While the combination of chemotherapy and stem cell therapy is hopeful as a treatment for cancer, there is conflicting literature at this time to unequivocally predict its efficacy in humans, as it can be dependent on type of chemotherapy, type of stem cells, and type of cancer (Somlo et al., 1994; VanderWalde et al., 2012; Qian et al., 2017). However, further insight into histopathologic and genetics may help evaluate how responsive a patient might be to these therapies (Zander et al., 2018). Reinfusion of peripheral blood progenitors is tolerated better, compared to bone marrow purging in patients with metastatic breast cancer and bone marrow infiltration (Myers et al., 1994). Risk factors that should be taken into account include patients that have received a doxorubicin treatment and breast cancer that has metastasized to the liver or lungs (Somlo et al., 1994). Bone marrow function returned to baseline in patients with high-risk breast cancer treated with autologous stem cell rescue following high dose CAW16 polychemotherapy consisting of doxorubicin, etoposide, and cyclophosphamide (Somlo et al., 1994).

A common treatment related event is dose limiting toxicity, ranging from life threatening to death (Brockstein and Williams, 1996; Demirer et al., 2003). Treatment regimens complications that progressed from organ specific toxicity included renal failure and pneumonia syndrome (Berry et al., 2011). Treatment

TABLE 1 | List of studies comparing standard treatment or chemotherapy and combination therapy with stem cell therapy.

\begin{tabular}{|c|c|c|}
\hline $\begin{array}{l}\text { Study author and } \\
\text { year published }\end{array}$ & Cancer type & Treatment \\
\hline $\begin{array}{l}\text { Stadtmauer et al. } \\
(2000)\end{array}$ & $\begin{array}{l}\text { Metastatic breast } \\
\text { cancer }\end{array}$ & $\begin{array}{l}\text { Maintenance verse high-dose chemotherapy and } \\
\text { autologous SC transplantation }\end{array}$ \\
\hline $\begin{array}{l}\text { Farquhar et al. } \\
(2005,2016)\end{array}$ & Breast cancer & $\begin{array}{l}\text { Conventional verse high dose chemotherapy and } \\
\text { BMSC/PSC autologous transplantation }\end{array}$ \\
\hline $\begin{array}{l}\text { Namouni et al. } \\
(1997)\end{array}$ & Retinoblastoma & $\begin{array}{l}\text { Maintenance vs. high-dose chemotherapy and carboplatin, } \\
\text { etoposide and cyclophosphamide and hematopoietic SC } \\
\text { rescue }\end{array}$ \\
\hline Motzer et al. (2007) & $\begin{array}{l}\text { Metastatic germ } \\
\text { cell tumors }\end{array}$ & $\begin{array}{l}\text { Standard chemotherapy dose vs. high-dose chemotherapy } \\
\text { and autologous hematopoietic SC }\end{array}$ \\
\hline $\begin{array}{l}\text { Graham et al. } \\
(1997)\end{array}$ & $\begin{array}{l}\text { High-risk and } \\
\text { recurrent pediatric } \\
\text { brain tumors }\end{array}$ & $\begin{array}{l}\text { Standard vs. high-dose chemotherapy and autologous } \\
\text { marrow rescue with or without peripheral-blood SC }\end{array}$ \\
\hline Yalçin et al. (2015) & $\begin{array}{l}\text { High-risk pediatric } \\
\text { neuroblastoma }\end{array}$ & $\begin{array}{l}\text { High-dose chemotherapy and autologous hematopoietic } \\
\text { stem cell rescue }\end{array}$ \\
\hline Berry et al. (2011) & Breast cancer & $\begin{array}{l}\text { High-dose chemotherapy and autologous hematopoietic } \\
\text { stem cell transplantation }\end{array}$ \\
\hline Delaye et al. (2021) & $\begin{array}{l}\text { Germ cell tumor } \\
\text { with brain } \\
\text { metastases }\end{array}$ & $\begin{array}{l}\text { High-dose chemotherapy followed by infusions of } \\
\text { autologous peripheral blood hematopoietic stem cells }\end{array}$ \\
\hline Ferreri et al. (2017) & $\begin{array}{l}\text { Primary CNS } \\
\text { lymphoma }\end{array}$ & $\begin{array}{l}\text { High-dose methotrexate-based chemotherapy followed by } \\
\text { autologous peripheral blood stem-cell transplantation } \\
\text { following }\end{array}$ \\
\hline $\begin{array}{l}\text { Illerhaus et al. } \\
\text { (2016) }\end{array}$ & $\begin{array}{l}\text { Primary CNS } \\
\text { lymphoma }\end{array}$ & $\begin{array}{l}\text { High-dose methotrexate-based chemotherapy with } \\
\text { autologous stem cell transplantation }\end{array}$ \\
\hline
\end{tabular}

Significant findings

The study found no difference between the two groups outcomes.

The study found little to no difference between the two groups' outcomes.

The study found improved outcomes in patients with interventional treatment at a 3-year survival disease-free time point. Patients that have co-occurring CNS disease did not have improved outcomes.

The study found no difference between the two groups' outcomes.

Interventional treatment shows it might improve outcomes.

The study found no difference between the two groups outcomes.

The study found improved outcomes in patients with high

The study found improved overall survival at 12 months.

The study found the therapy effective at 2-year progression-free survival

The study found a complete response 30 -days post treatment 

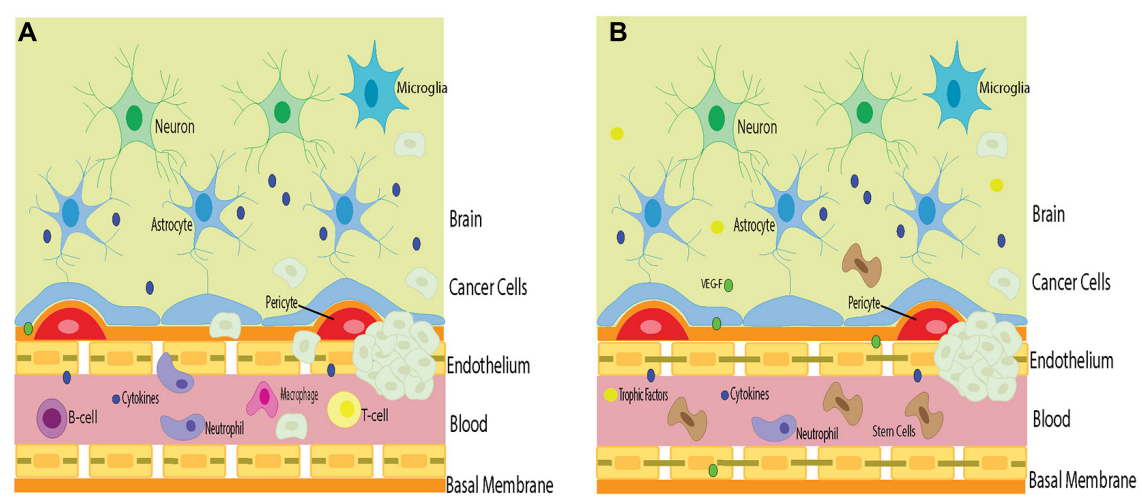

FIGURE 1 | The barriers in stem cell therapy for brain cancers. Cancer cells in the brain circumvent the host immune surveillance, in part, due to their own tumor barrier. (A) Inflammation that accompanies cancer cell infiltration may compromise BBB permeability, allowing inflammatory cells to penetrate the brain and exacerbate tumorigenesis. (B) Stem cell therapy directed at repairing the BBB may prevent the influx of deleterious inflammatory cells into the brain and cancer cells and improve the surrounding environment. However, stem cells may also facilitate the potency of tumor barrier, allowing angiogenic and vasculogenic support to the cancer cells thereby aiding in tumorigenesis. Such risk-to-benefit outcome warrants a careful examination of advancing stem cell therapy for cancer treatment.

following high dose chemotherapy and autologous stem cell therapy may produce relapse (Somlo et al., 1994). There is no evidence of prolonged survival in patients with high-risk breast cancer who were treated with high dose chemotherapy in combination with autologous hematopoietic stem cell transplantation than a control group (Berry et al., 2011). High dose chemotherapy in combination with stem cells for breast cancer patients show long-term event-free survival, but an overall survival benefit is not significant (Berry et al., 2011). Likewise, high dose adjuvant chemotherapy with autologous hematopoietic stem cells has no significant overall survival value compared to control (Steenbruggen et al., 2020). However, there is evidence in breast cancers that involve at least ten axillary lymph nodes, HER2 negative breast cancer, and triple negative breast cancer (Steenbruggen et al., 2020).

There is no evidence that high-dose chemotherapy treatment in combination with stem cell therapy improves the median survival rate in comparison to the conventionaldose chemotherapy treatment in metastatic breast cancer (Stadtmauer et al., 2000). No significant difference accompanies the overall survival rate nor the time of progression between the participants in the treatment groups; however, further analysis revealed a potential survival advantage for women over 42 years old who only received conventional chemotherapy (Stadtmauer et al., 2000). Although not statistically significant, this finding warrants further investigation. In addition, the high-chemo stem cells group had a higher hazard ratio than the conventional-dose group. This indicates a lower likelihood of survival. Furthermore, the patient group who received a high-dose chemotherapy with stem cells showed a higher incidence of moderate and severe non-fatal adverse effects, suggesting that this type of treatment has a greater toxicity than the conventional chemotherapy approach (Stadtmauer et al., 2000).

Patients with intermediate to high grade lymphoma, who relapsed or were unresponsive to the conventional chemotherapy, demonstrated $40-50 \%$ long term disease-free survival if they receive a high-dose chemotherapy with autologous bone marrow transplant (ABMT) as the salvage treatment (Bosly et al., 1992; Douer et al., 1996). These findings offer evidence toward the efficacy of this treatment since patients who only receive conventional chemotherapy are typically considered to be incurable. In addition, patients with metastatic breast cancer who responded to the conventional-dose therapy and then underwent ABMT had a greater chance of achieving complete remission (Douer et al., 1996). Furthermore, newly diagnosed patients with stage II or III breast cancer and 10 or more lymph nodes had a lower 5-year recurrence rate if they were treated with ABMT compared to those treated with the standard therapy (Douer et al., 1996).

High-dose chemotherapy with autologous bone marrow stem cell transplantation can cause serious side effects (Farquhar et al., 2005). Six randomized trials tested the effectiveness of high-dose chemotherapy combined with autologous bone marrow stem cell transplantation to conventional chemotherapy in women with metastatic breast cancer (Farquhar et al., 2005). The high-dose treatment group survived significantly longer prior to experiencing a relapse of cancer. However, an increase in their overall survival rate is not seen when compared to the conventional treatment group. The side effects associated with treatment were worse in the high-dose chemotherapy with autograft treatment groups. The women that received highdose chemotherapy with autograft were far more likely to experience severe adverse side effects such as hematological toxicity, sepsis, organ toxicity, and/or gastrointestinal toxicity (Farquhar et al., 2005). Even though in most cases these toxic effects were short-lived, the women reported experiencing continuous significant impairment 6-9 months after treatment (Farquhar et al., 2005).

\section{Evaluation of the Treatment of Brain Cancer With the Combination of Chemotherapy and Stem Cell Therapies}

High-dose chemotherapy followed by infusions of autologous peripheral blood hematopoietic stem cells in patients with germ 
cell tumor with brain metastases found that the combination treatment had an overall survival of 12 months (Delaye et al., 2021). It should be noted that the results are limited as this sample size is small (Delaye et al., 2021). A phase 2 randomized trial, International Extranodal Lymphoma Study Group-32 (IELSG32), examined the efficacy of autologous peripheral blood stem-cell transplantation compared to wholebrain radiotherapy following high-dose methotrexate-based chemoimmunotherapy in patients with primary CNS lymphoma (Ferreri et al., 2017). This trial found that autologous stemcell transplantation combination therapy was effective and there were no clinical significant differences to whole-brain radiotherapy in 2 year progression-free survival (Ferreri et al., 2017). Specifically, autologous stem-cell transplantation was associated with hematological toxicity and could be considered a possible option for patients following further research (Ferreri et al., 2017). Similarly, a phase 2 trial, Freiburg ZNS-NHL, examined the safety and efficacy of high-dose methotrexate-based chemotherapy with autologous stem cell transplantation with thiotepa and carmustine in patients with primary CNS lymphoma (Illerhaus et al., 2016). They found a majority of patients achieved a complete response in 30 days however toxicity was prevalent following induction of treatment (Illerhaus et al., 2016).

\section{Stem Cell Contamination}

Peripheral blood stem cells (PBSCs) therapy may be beneficial to the cancer patients who are undergoing chemotherapy, in particular for those who receive the high-dose regimen due to its presumed role in the restoration of the immune system. However, there is a chance that during this procedure the PBSC cells become contaminated with the cancer cells, increasing the risk of micro-metastasis after the infusion of PBSC (Kasimir-Bauer et al., 2001). Patients with no or a low number of micro-metastatic cells in the bone marrow before and after chemotherapy, and no contamination of PBSCs, achieved complete remission (KasimirBauer et al., 2001). This elucidates the potential implication of novel contaminated stem cell therapy to the overall outcomes to cancer treatment.

Tumor cells contained in autografts can contribute to relapse in certain types of cancer (Shimoni and Körbling, 2002). This highlights that although stem cells from blood may have less contamination from tumor cells compared to those of the bone marrow, they are still frequently contaminated. There is an association between the contamination of stem cell in autografts and a decrease in disease-free survival, which complements these results (Shimoni and Körbling, 2002).

Stem cells can have a detrimental effect on the overall outcome of patients with certain types of cancer. Stem cell therapy

\section{REFERENCES}

Abbott, N. J., Ronnback, L., and Hansson, E. (2006). Astrocyte-endothelial interactions at the blood-brain barrier. Nat. Rev. Neurosci. 7, 41-53. doi: 10 . $1038 / \mathrm{nrn} 1824$

Ahn, S. Y. (2020). The Role of MSCs in the tumor microenvironment and tumor progression. Anticancer Res. 40, 3039-3047. doi: 10.21873/anticanres.14284/ combined with chemotherapy may exacerbate specific cancers. It is important to carefully consider such an approach. Adjusting the dosage, timing, and delivery of both strategies may be warranted to observe better outcomes. Identifying these patient populations who may be more vulnerable to worsened cancer outcomes also needs to be considered as part of differential diagnosis before contemplating such combined therapy for treating specific cancers. Because cancer cells possess their own tumor barrier, unique from the $\mathrm{BBB}$, migration of stem cells and chemotherapy targeting the cancer cell tumor barrier and the BBB may circumvent triggering both barriers' angiogenic and vasculogenic properties, which while beneficial for BBB, may aid the tumor barrier potentiation of cancer cells' growth (Figure 1).

\section{CONCLUSION}

Brain metastases may disrupt BBB and cause inflammation in the brain that exacerbates their growth rate. While it is shown that stimulating angiogenesis can lead to leaky blood vessels, we hypothesis in "3.Stem Cell Rescue of the Pathologic BBB" that metastatic cancer might have a similar effect of ameliorating similar to bone marrow-derived stem cells, expressing EPC phenotypes effect in stroke models, as we suggested in the following paragraph that stem cell therapy will ameliorate $\mathrm{BBB}$ damage via angiogenesis, reduce brain inflammation, and decrease brain tumor growth rate. Demonstrating this hypothesized stem cell treatment potentiates repair of the leaky $\mathrm{BBB}$ through stimulation of angiogenesis and vasculogenesis will be highly significant for basic science, translational, and clinical applications. Sequestration of inflammation within the brain via stem cell therapy may hinder the growth of malignant tumors and may present as a novel avenue for combating metastatic cancer and glioblastoma.

\section{AUTHOR CONTRIBUTIONS}

NS, AS, BB, MS, DC, CK, HZ, SA, Z-JW, FS, AL, GR, JV, $A M, J-Y L$, and CB: conceptualization, literature analysis, writingreview, and editing. $\mathrm{CB}$ : supervision, project administration, and funding acquisition. All authors have read and agreed to the published version of the manuscript.

\section{FUNDING}

CB was funded by the National Institutes of Health (NIH) R01NS090962, NIH R01NS102395 and NIH R21NS109575.

Al Ahmad, A., Taboada, C. B., Gassmann, M., and Ogunshola, O. O. (2011). Astrocytes and pericytes differentially modulate blood-brain barrier characteristics during development and hypoxic insult. .J Cereb. Blood Flow Metab. 31, 693-705. doi: 10.1038/jcbfm.2010.148

Almeida, E. B., Silva, K. P. H., Paixão, V., Amaral, J. B. D., Rossi, M., XavierNavarro, R. A., et al. (2019). Mixture of polyunsaturated fatty acids $\omega-3$ and $\omega-6$ reduces melanoma growth by inhibiting inflammatory mediators in the 
murine tumor microenvironment. Internal. J. Molr. Sci. 20:3765. doi: 10.3390/ ijms20153765

Andrzejewska, A., Dabrowska, S., Lukomska, B., and Janowski, M. (2021). Mesenchymal stem cells for neurological disorders. Adv. Sci. (Weinh). 8:2002944. doi: 10.1002/advs.202002944

Antonucci, I., Stuppia, L., Kaneko, Y., Yu, S., Tajiri, N., Bae, E. C., et al. (2011) Amniotic fluid as a rich source of mesenchymal stromal cells for transplantation therapy. Cell Transplant. 20, 789-795. doi: 10.3727/096368910X539074

Aragon-Ching, J. B., and Zujewski, J. A. (2007). CNS metastasis: an old problem in a new guise. Clin. Cancer Res. 13, 1644-1647.

Armulik, A., Genové, G., Mäe, M., Nisancioglu, M. H., Wallgard, E., Niaudet, C., et al. (2010). Pericytes regulate the blood-brain barrier. Nature 468, 557-561. doi: $10.1038 /$ nature09522

Arvanitis, C. D., Ferraro, G. B., and Jain, R. K. (2020). The blood-brain barrier and blood-tumour barrier in brain tumours and metastases. Nat. Rev. Cancer 20, 26-41. doi: 10.1038/s41568-019-0205-x

Ashrafizadeh, M., Zarrabi, A., Hushmandi, K., Kalantari, M., Mohammadinejad, R., Javaheri, T., et al. (2020). Association of the epithelial-mesenchymal transition (EMT) with cisplatin resistance. Int. J. Mol. Sci. 21:4002. doi: 10.3390/ ijms 21114002

Atiya, H., Frisbie, L., Pressimone, C., and Coffman, L. (2020). Mesenchymal stem cells in the tumor microenvironment. Adv. Exp. Med. Biol. 1234, 31-42. doi: 10.1007/978-3-030-37184-5 3

Ayloo, S., and Gu, C. (2019). Transcytosis at the blood-brain barrier. Curr. Opin. Neurobiol. 57, 32-38. doi: 10.1016/j.conb.2018.12.014

Ayob, A. Z., and Ramasamy, T. S. (2018). Cancer stem cells as key drivers of tumour progression. J. Biomed. Sci. 25:20. doi: 10.1186/s12929-018-0426-4

Babak, M. V., Zalutsky, M. R., and Balyasnikova, I. V. (2020). Heterogeneity and vascular permeability of breast cancer brain metastases. Cancer Lett. 489, 174-181. doi: 10.1016/j.canlet.2020.06.012

Ballabio, A., and Bonifacino, J. S. (2020). Lysosomes as dynamic regulators of cell and organismal homeostasis. Nat. Rev. Mol. Cell Biol. 21, 101-118. doi: 10.1038/s41580-019-0185-4

Bao, Q., Zhao, Y., Niess, H., Conrad, C., Schwarz, B., Jauch, K. W., et al. (2012). Mesenchymal stem cell-based tumor-targeted gene therapy in gastrointestinal cancer. Stem Cells Dev. 21, 2355-2363. doi: 10.1089/scd.2012.0060

Batlle, E., and Clevers, H. (2017). Cancer stem cells revisited. Nat. Med. 23:1124. doi: $10.1038 / \mathrm{nm} .4409$

Becerra, S. P., and Notario, V. (2013). The effects of PEDF on cancer biology: Mechanisms of action and therapeutic potential. Nat. Rev. Cancer 13, 258-271. doi: $10.1038 / \mathrm{nrc} 3484$

Bernardo, G., Cuzzoni, Q., Strada, M. R., Bernardo, A., Brunetti, G., Jedrychowska, I., et al. (2002). First-line chemotherapy with vinorelbine, gemcitabine, and carboplatin in the treatment of brain metastases from non-small-cell lung cancer: A phase II study. Cancer Invest. 20, 293-302. doi: 10.1081/cnv120001173

Berry, D. A., Ueno, N. T., Johnson, M. M., Lei, X., Caputo, J., Rodenhuis, S., et al. (2011). High-dose chemotherapy with autologous stem-cell support as adjuvant therapy in breast cancer: overview of 15 randomized trials. J. Clin. Oncol. 29, 3214-3223. doi: 10.1200/JCO.2010.32.5910

Bhowmik, A., Khan, R., and Ghosh, M. K. (2015). Blood brain barrier: a challenge for effectual therapy of brain tumors. Biomed. Res. Int. 2015:32094. doi: 10.1155/ $2015 / 320941$

Blanchette, M. and Daneman, R. (2015). Formation and maintenance of the BBB. Mech. Dev. 138, 8-16. doi: 10.1016/j.mod.2015.07.007

Boedtkjer, E., and Pedersen, S. F. (2020). The acidic tumor microenvironment as a driver of cancer. Annu. Rev. Physiol. 82, 103-126. doi: 10.1146/annurevphysiol-021119-034627

Boire, A., Brastianos, P. K., Garzia, L., and Valiente, M. (2020). Brain metastasis. Nat. Rev. Cancer 20, 4-11. doi: 10.1038/s41568-019-0220-y

Borlongan, C. V., Lind, J. G., Dillon-Carter, O., Yu, G., Hadman, M., Cheng, C., et al. (2004). Bone marrow grafts restore cerebral blood flow and blood brain barrier in stroke rats. Brain Res. 1010, 108-116. doi: 10.1016/j.brainres.2004.02. 072

Bosly, A., Coiffier, B., Gisselbrecht, C., Tilly, H., Auzanneau, G., Andrien, F., et al. (1992). Bone marrow transplantation prolongs survival after relapse in aggressive-lymphoma patients treated with the NHL-84 regimen. J. Clin. Oncol. 10:1615. doi: 10.1200/JCO.1992.10.10.1615
Brighi, C., Reid, L., Genovesi, L. A., Kojic, M., Millar, A., Bruce, Z., et al. (2020). Comparative study of preclinical mouse models of high-grade glioma for nanomedicine research: the importance of reproducing blood-brain barrier heterogeneity. Theranostics 10, 6361-6371. doi: 10.7150/thno.46468

Brockstein, B. E., and Williams, S. F. (1996). High-dose chemotherapy with autologous stem cell rescue for breast cancer: yesterday, today and tomorrow. Stem Cells 14, 79-89.

Brown, J. M., and Giaccia, A. J. (1998). The unique physiology of solid tumors: Opportunities (and problems) for cancer therapy. Cancer Res. 58, 1408-1416.

Bush, T. G., Puvanachandra, N., Horner, C. H., Polito, A., Ostenfeld, T., Svendsen, C. N., et al. (1999). Leukocyte infiltration, neuronal degeneration, and neurite outgrowth after ablation of scar-forming, reactive astrocytes in adult transgenic mice. Neuron 23, 297-308. doi: 10.1016/s0896-6273(00)80781-3

Byun, C. S., Hwang, S., Woo, S. H., Kim, M. Y., Lee, J. S., Lee, J. I., et al. (2020). Adipose tissue-derived mesenchymal stem cells suppress growth of Huh7 hepatocellular carcinoma cells via interferon (IFN)- $\beta$-mediated JAK/STAT1 pathway in vitro. Int. J. Med. Sci. 17, 609-619. doi: 10.7150/ijms.41354

Cable, J., Fuchs, E., Weissman, I., Jasper, H., Glass, D., Rando, T. A., et al. (2020). Adult stem cells and regenerative medicine-a symposium report. Ann. N.Y. Acad. Sci. 1462, 27-36.

Carmen-Orozco, R. P., Dávila-Villacorta, D. G., Cauna, Y., Bernal-Teran, E. G., Bitterfeld, L., Sutherland, G. L., et al. (2019). Blood-brain barrier disruption and angiogenesis in a rat model for neurocysticercosis. J. Neurosci. Res. 97, 137-148. doi: 10.1002/jnr.2433

Castelli, V., Antonucci, I., d'Angelo, M., Tessitore, A., Zelli, V., Benedetti, E., et al. (2021). Neuroprotective effects of human amniotic fluid stem cellsderived secretome in an ischemia/reperfusion model. Stem Cells Transl. Med. 10, 251-266. doi: 10.1002/sctm.20-0268

Chae, Y. C., and Kim, J. H. (2018). Cancer stem cell metabolism: target for cancer therapy. BMB Rep. 51, 319-326. doi: 10.5483/bmbrep.2018.51.7.112

Chen, B. B., Lu, Y. S., Lin, C. H., Chen, W. W., Wu, P. F., Hsu, C. Y., et al. (2016). A pilot study to determine the timing and effect of bevacizumab on vascular normalization of metastatic brain tumors in breast cancer. BMC Cancer 16:466. doi: 10.1186/s12885-016-2494-8

Chen, Q., Boire, A., Jin, X., Valiente, M., Er, E. E., Lopez-Soto, A., et al. (2016). Carcinoma-astrocyte gap junctions promote brain metastasis by cGAMP transfer. Nature 533, 493-498. doi: 10.1038/nature18268

Chen, Z., Feng, X., Herting, C. J., Garcia, V. A., Nie, K., Pong, W. W., et al. (2017). Cellular and molecular identity of tumor-associated macrophages in glioblastoma. Cancer Res. 77, 2266-2278.

Chen, Z. J., Broaddus, W. C., Viswanathan, R. R., Raghavan, R., and Gillies, G. T. (2002). Intraparenchymal drug delivery via positive-pressure infusion: experimental and modeling studies of poroelasticity in brain phantom gels. IEEE Trans. Biomed. Eng. 49, 85-96. doi: 10.1109/10.979348

Chiou, G. Y., Chien, C. S., Wang, M. L., Chen, M. T., Yang, Y. P., Yu, Y. L., et al. (2013). Epigenetic regulation of the miR142-3p/interleukin-6 circuit in glioblastoma. Mol. Cell. 52, 693-706. doi: 10.1016/j.molcel.2013.11.009

Chu, D. T., Nguyen, T. T., Tien, N. L. B., Tran, D. K., Jeong, J. H., Anh, P. G., et al. (2020). Recent progress of stem cell therapy in cancer treatment: Molecular mechanisms and potential applications. Cells 9:563. doi: 10.3390/cells 9030563

Copelan, E. A. (2006). Hematopoietic stem-cell transplantation. N. Engl. J. Med. 354, 1813-1826. doi: 10.1056/NEJMra052638

Curtaz, C. J., Schmitt, C., Blecharz-Lang, K. G., Roewer, N., Wöckel, A., and Burek, M. (2020). Circulating MicroRNAs and blood-brain-barrier function in breast cancer metastasis. Curr. Pharm. Des. 26, 417-1427. doi: 10.2174/ 1381612826666200316151720

Da Ros, M., De Gregorio, V., Iorio, A. L., Giunti, L., Guidi, M., De Martino, M., et al. (2018). Glioblastoma chemoresistance: The double play by microenvironment and blood-brain barrier. Int. J. Mol. Sci. 19:2879. doi: 10.3390/ijms19102879

Daneman, R., and Prat, A. (2015). The blood-brain barrier. Cold Spring Harb. Perspect Biol. 7:a020412. doi: 10.1101/cshperspect.a020412

Daneman, R., Zhou, L., Kebede, A. A., and Barres, B. A. (2010). Pericytes are required for blood brain barrier integrity during embryogenesis. Nature 468, 562-566. doi: 10.1038/nature09513

Deeken, J. F., and Loscher, W. (2007). The blood-brain barrier and cancer: Transporters, treatment, and Trojan horses. Clin. Cancer Res. 13, 1663-1674. doi: 10.1158/1078-0432.CCR-06-2854 
Dejana, E. (2004). Endothelial cell-cell junctions: Happy together. Nat. Rev. Mol. Cell Biol. 5, 261-270. doi: 10.1038/nrm1357

Delaye, M., Benderra, M. A., Deforceville, L., Larghero, J., Parquet, N., Culine, S., et al. (2021). High-dose chemotherapy in germ cell cancer patients with brain metastases: experience of an expert center. Am. J. Clin. Oncol. 44, 423-428. doi: 10.1097/COC.0000000000000836

Demirer, T., Uysal, V., Ayll, M., Genc, Y., Ilhan, O., Koc, H., et al. (2003). Highdose thiotepa, melphalan and carboplatin (TMCb) followed by autologous stem cell transplantation in patients with advanced breast cancer: a retrospective evaluation. Bone Marrow Transplant. 31, 755-761. doi: 10.1038/sj.bmt.1703918

Díaz-Flores, L., Gutiérrez, R., and Varela, H. (1994). Angiogenesis: An update. Histol. Histopathol. 9, 807-843.

Dong, X. (2018). Current strategies for brain drug delivery. Theranostics 8, 14811493. doi: $10.7150 /$ thno. 21254

D’Orazi, G., Cordani, M., and Cirone, M. (2021). Oncogenic pathways activated by pro-inflammatory cytokines promote mutant p53 stability: Clue for novel anticancer therapies. Cell Mol. Life Sci. 78, 1853-1860. doi: 10.1007/s00018-02003677-7

Douer, D., Levine, A., French Anderson, W., Gordon, M., Groshen, S., Khan, A., et al. (1996). High-dose chemotherapy and autologous bone marrow plus peripheral blood stem cell transplantation for patients with lymphoma or metastatic breast cancer: Use of marker genes to investigate hemaptopoietic reconstitution in adults. Hum. Gene Ther. 7, 669-684.

Drommelschmidt, K., Serdar, M., Bendix, I., Herz, J., Bertling, F., Prager, S., et al. (2017). Mesenchymal stem cell-derived extracellular vesicles ameliorate inflammation-induced preterm brain injury. Brain Behav. Immun. 60, 220-232.

Du, L., Liang, Q., Ge, S., Yang, C., and Yang, P. (2019). The growth inhibitory effect of human gingiva-derived mesenchymal stromal cells expressing interferon- $\beta$ on tongue squamous cell carcinoma cells and xenograft model. Stem Cell Res. Ther. 10:224.

Dubois, L. G., Campanati, L., Righy, C., D’Andrea-Meira, I., Spohr, T. C., PortoCarreiro, I., et al. (2014). Gliomas and the vascular fragility of the blood brain barrier. Front. Cell Neurosci. 8:418. doi: 10.3389/fncel.2014.00418

Dzobo, K., Senthebane, D. A., Ganz, C., Thomford, N. E., Wonkam, A., and Dandara, C. (2020). Advances in therapeutic targeting of cancer stem cells within the tumor microenvironment: An updated review. Cells 9:1896. doi: $10.3390 /$ cells 9081896

Eisen, T., Marais, R., Affolter, A., Lorigan, P., Robert, C., Corrie, P., et al. (2011). Sorafenib and dacarbazine as first-line therapy for advanced melanoma: phase I and open-label phase II studies. Br. J. Cancer 105, 353-359. doi: 10.1038/bjc. 2011.257

Eldahshan, W., Fagan, S. C., and Ergul, A. (2019). Inflammation within the neurovascular unit: Focus on microglia for stroke injury and recovery. Pharmacol. Res. 147:104349. doi: 10.1016/j.phrs.2019.104349

Eve, D. J., Steiner, G., Mahendrasah, A., Sanberg, P. R., Kurien, C., Thomson, A., et al. (2018). Reduction of microhemorrhages in the spinal cord of symptomatic ALS mice after intravenous human bone marrow stem cell transplantation accompanies repair of the blood-spinal cord barrier. Oncotarget 9, 1062110634. doi: 10.18632 /oncotarget.24360

Farquhar, C., Marjoribanks, J., Basser, R., Hetrick, S., and Lethaby, A. (2005). High dose chemotherapy and autologous bone marrow or stem cell transplantation versus conventional chemotherapy for women with metastatic breast cancer. Cochrane Database Syst. Rev. 2005:CD003142. doi: 10.1002/ 14651858.CD003142.pub2

Farquhar, C., Marjoribanks, J., Lethaby, A., and Azhar, M. (2016). High-dose chemotherapy and autologous bone marrow or stem cell transplantation versus conventional chemotherapy for women with early poor prognosis breast cancer. Cochrane Database Syst. Rev. 2016:CD003139. doi: 10.1002/14651858. CD003139.pub3

Ferreri, A. J. M., Cwynarski, K., Pulczynski, E., Fox, C. P., Schorb, E., La Rosée, P., et al. (2017). Whole-brain radiotherapy or autologous stem-cell transplantation as consolidation strategies after high-dose methotrexate-based chemoimmunotherapy in patients with primary CNS lymphoma: results of the second randomisation of the International Extranodal Lymphoma Study Group-32 phase 2 trial. Lancet Haematol. 4, e510-e523. doi: 10.1016/S23523026(17)30174-6

Fidler, I. J. (2011). The role of the organ microenvironment in brain metastasis. Semin. Cancer Biol. 21, 107-112. doi: 10.1016/j.semcancer.2010.12.009
Fidler, I. J., Balasubramanian, K., Lin, Q., Kim, S. W., and Kim, S. J. (2010). The brain microenvironment and cancer metastasis. Mol. Cell. 30, 93-98. doi: 10.1007/s10059-010-0133-9

Finger, E. C., and Giaccia, A. J. (2010). Hypoxia, inflammation, and the tumor microenvironment in metastatic disease. Cancer Metastasis Rev. 29, 285-293. doi: 10.1007/s10555-010-9224-5

Folkman, J. (1990). What is the evidence that tumors are angiogenesis dependent? J. Natl. Cancer Inst. 82, 4-6. doi: 10.1093/jnci/82.1.4

Fujita, A., Fukuoka, S., Takabatake, H., Tagaki, S., and Sekine, K. (2000). Combination chemotherapy of cisplatin, ifosfamide, and irinotecan with rhGCSF support in patients with brain metastases from non-small cell lung cancer. Oncology 59, 291-295. doi: 10.1159/000012185

Garbuzova-Davis, S., and Borlongan, C. V. (2021). Stem cell-derived extracellular vesicles as potential mechanism for repair of microvascular damage within and outside of the central nervous system in amyotrophic lateral sclerosis: perspective schema. Neural Regen. Res. 6, 680-681.

Garbuzova-Davis, S., Ehrhart, J., Mustafa, H., Llauget, A., Boccio, K. J., Sanberg, P. R., et al. (2019a). Phenotypic characteristics of human bone marrow-derived endothelial progenitor cells in vitro support cell effectiveness for repair of the blood-spinal cord barrier in ALS. Brain Res. 1724:146428. doi: 10.1016/j. brainres.2019.146428

Garbuzova-Davis, S., Kurien, C., Haller, E., Eve, D. J., Navarro, S., Steiner, G., et al. (2019b). Human bone marrow endothelial progenitor cell transplantation into symptomatic ALS mice delays disease progression and increases motor neuron survival by repairing blood-spinal cord barrier. Sci. Rep. 9:5280. doi: 10.1038/s41598-019-41747-4

Garbuzova-Davis, S., Haller, E., Lin, R., and Borlongan, C. V. (2017). Intravenously transplanted human bone marrow endothelial progenitor cells engraft within brain capillaries, preserve mitochondrial morphology, and display pinocytotic activity toward blood-brain barrier repair in ischemic stroke rats. Stem Cells 35 , 1246-1258. doi: 10.1002/stem.2578

Garbuzova-Davis, S., Haller, E., Navarro, S., Besong, T. E., Boccio, K. J., Hailu, S., et al. (2018). Transplantation of human bone marrow stem cells into symptomatic ALS mice enhances structural and functional blood-spinal cord barrier repair. Exp. Neurol. 310, 33-47. doi: 10.1016/j.expneurol.2018.08.012

Garbuzova-Davis, S., Willing, A. E., Ehrhart, J., Wang, L., Sanberg, P. R., and Borlongan, C. V. (2020). Cell-free extracellular vesicles derived from human bone marrow endothelial progenitor cells as potential therapeutics for microvascular endothelium restoration in ALS. Neuromol. Med. 22, 503-516. doi: 10.1007/s12017-020-08607-1

Ge, S., Jiang, X., Paul, D., Song, L., Wang, X., and Pachter, J. S. (2019). Human ES-derived MSCs correct TNF- $\alpha$-mediated alterations in a blood-brain barrier model. Fluids Barriers CNS. 16:18. doi: 10.1186/s12987-019-0138-5

Gerstner, E. R., and Fine, R. L. (2007). Increased permeability of the blood-brain barrier to chemotherapy in metastatic brain tumors: establishing a treatment paradigm. J. Clin. Oncol. 25, 2306-2312. doi: 10.1200/JCO.2006.10.0677

Gowda, R., Robertson, B. M., Iyer, S., Barry, J., Dinavahi, S. S., and Robertson, G. P. (2020). The role of exosomes in metastasis and progression of melanoma. Cancer Treat. Rev. 85:101975. doi: 10.1016/j.ctrv.2020.101975

Graham, K., and Unger, E. (2018). Overcoming tumor hypoxia as a barrier to radiotherapy, chemotherapy and immunotherapy in cancer treatment. Int. J. Nanomed. 13, 6049-6058. doi: 10.2147/IJN.S140462

Graham, M. L., Hardon, J. E. II, Casey, J. R., Chaffee, S., Ciocci, G. H., Krischer, J. P., et al. (1997). High-dose chemotherapy with autologous stem-cell rescue in patients with recurrent and high-risk pediatric brain tumors. J. Clin. Oncol. 15, 1814-1823.

Groothuis, D. R., Vriesendorp, F. J., Kupfer, B., Warnke, P. C., Lapin, G. D., Kuruvilla, A., et al. (1991). Quantitative measurements of capillary transport in human brain tumors by computed tomography. Ann. Neurol. 30, 581-588. doi: 10.1002/ana.410300411

Guo, X., Xue, H., Shao, Q., Wang, J., Guo, X., Chen, X., et al. (2016). Hypoxia promotes glioma-associated macrophage infiltration via periostin and subsequent M2 polarization by upregulating TGF-beta and M-CSFR. Oncotarget 7, 80521-80542. doi: 10.18632/oncotarget.11825

Gutova, M., Goldstein, L., Metz, M., Hovsepyan, A., Tsurkan, L. G., Tirughana, R., et al. (2016). Optimization of a neural stem-cell-mediated carboxylesterase/irinotecan gene therapy for metastatic neuroblastoma. Mol. Ther. Oncol. 14, 67-76. doi: 10.1016/j.omto.2016.11.004 
Gutzmer, R., Vordermark, D., Hassel, J. C., Krex, D., Wendl, C., Schadendorf, D., et al. (2020). Melanoma brain metastases-Interdisciplinary management recommendations 2020. Cancer Treat. Rev. 89:102083.

Hagenhoff, A., Bruns, C. J., Zhao, Y., von Lüttichau, I., Niess, H., Spitzweg, C., et al. (2016). Harnessing mesenchymal stem cell homing as an anticancer therapy. Expert Opin. Biol. Ther. 16, 1079-1092. doi: 10.1080/14712598.2016.1196179

Hass, R., von, der Ohe, J., and Ungefroren, H. (2020). Impact of the tumor microenvironment on tumor heterogeneity and consequences for cancer cell plasticity and stemness. Cancers (Basel). 12:3716. doi: 10.3390/cancers12123716

Hatfield, S. M., Kjaergaard, J., Lukashev, D., Schreiber, T. H., Belikoff, B., Abbott, R., et al. (2015). Immunological mechanisms of the antitumor effects of supplemental oxygenation. Sci. Transl. Med. 7:277ra3. doi: 10.1126/ scitranslmed.aaa1260

Heath, V. L., and Bicknell, R. (2009). Anticancer strategies involving the vasculature. Nat. Rev. Clin. Oncol. 6, 395-404. doi: 10.1038/nrclinonc.2009.52

Heo, J. R., Hwang, K. A., Kim, S. U., and Choi, K. C. (2019). A potential therapy using engineered stem cells prevented malignant melanoma in cellular and xenograft mouse models. Cancer Res. Treat. 51, 797-811. doi: 10.4143/crt.2018. 364

Herndon, J. M., Tome, M. E., and Davis, T. P. (2017). "Development and Maintenance of The Blood-Brain Barrier," in Primer on Cerebrovascular Diseases, Second Edn, ed. L. R. Caplan (Cambridge: Academic Press), 51-56.

Hinshaw, D. C., and Shevde, L. A. (2019). The tumor microenvironment innately modulates cancer progression. Cancer Res. 79, 4557-4566. doi: 10.1158/00085472.CAN-18-3962

Hong, S. H., Lee, H. J., An, J., Lim, I., Borlongan, C., Aboody, K. S., et al. (2013). Human neural stem cells expressing carboxyl esterase target and inhibit tumor growth of lung cancer brain metastases. Cancer Gene Ther. 20, 678-682. doi: 10.1038/cgt.2013.69

Hong, X., Miller, C., Savant-Bhonsale, S., and Kalkanis, S. N. (2009). Antitumor treatment using interleukin-12-secreting marrow stromal cells in an invasive glioma model. Neurosurgery 64, 1139-1146.

Hu, Q., Sun, W., Wang, J., Ruan, H., Zhang, X., Ye, Y., et al. (2018). Conjugation of haematopoietic stem cells and platelets decorated with anti-PD-1 antibodies augments anti-leukaemia efficacy. Nat. Biomed. Eng. 2, 831-840. doi: 10.1038/ s41551-018-0310-2

Huang, X., Hussain, B., and Chang, J. (2021). Peripheral inflammation and bloodbrain barrier disruption: effects and mechanisms. CNS Neurosci. Ther. 27, 36-47. doi: 10.1111/cns.13569

Huang, Y., Chen, S., Luo, Y., and Han, Z. (2020). Crosstalk between inflammation and the BBB in Stroke. Curr. Neuropharmacol. 18, 1227-1236. doi: 10.2174/ 1570159X18666200620230321

Iliopoulos, D., Hirsch, H. A., and Struhl, K. (2009). An epigenetic switch involving NF-kappaB, Lin28, Let-7 MicroRNA, and IL6 links inflammation to cell transformation. Cell 139, 693-706. doi: 10.1016/j.cell.2009.10.014

Illerhaus, G., Kasenda, B., Ihorst, G., Egerer, G., Lamprecht, M., Keller, U., et al. (2016). High-dose chemotherapy with autologous haemopoietic stem cell transplantation for newly diagnosed primary CNS lymphoma: a prospective, single-arm, phase 2 trial. Lancet Haematol. 3, e388-e397. doi: 10.1016/S23523026(16)30050-3

Iwadate, Y. (2016). Epithelial-mesenchymal transition in glioblastoma progression. Oncol. Lett. 11, 1615-1620. doi: 10.3892/ol.2016.4113

Jain, R. K. (2005). Normalization of tumor vasculature: An emerging concept in antiangiogenic therapy. Science 307, 58-62. doi: 10.1126/science.1104819

Kabat, M., Bobkov, I., Kumar, S., and Grumet, M. (2020). Trends in mesenchymal stem cell clinical trials 2004-2018: Is efficacy optimal in a narrow dose range? Stem Cells Transl. Med. 9, 17-27. doi: 10.1002/sctm.19-0202

Kaneko, Y., Tajiri, N., Staples, M., Reyes, S., Lozano, D., Sanberg, P. R., et al. (2015). Bone marrow-derived stem cell therapy for metastatic brain cancers. Cell Transplant. 24, 625-630. doi: 10.3727/096368914X685096

Karimkhani, C., Green, A. C., Nijsten, T., Weinstock, M. A., Dellavalle, R. P., Naghavi, M., et al. (2017). The global burden of melanoma: results from the global burden of disease study. Br. J. Dermatol. 177, 134-140. doi: 10.1111/bjd. 15510

Kasimir-Bauer, S., Mayer, S., Bojko, P., Borquez, D., Neumann, R., and Seeber, S. (2001). Survival of tumor cells in stem cell preparations and bone marrow of patients with high-risk or metastatic breast cancer after receiving dose-intensive or high-dose chemotherapy. Clin. Cancer Res. 7, 1582-1589.
Korfel, A., Oehm, C., Von Pawel, J., Keppler, U., Deppermann, M., Kaubitsch, S., et al. (2002). Response to topotecan of symptomatic brain metastases of smallcell lung cancer also after whole-brain irradiation: A multicentre phase II study. Eur. J. Cancer 38, 1724-1729. doi: 10.1016/s0959-8049(02)00140-5

Korkaya, H., Kim, G. I., Davis, A., Malik, F., Henry, N. L., Ithimakin, S., et al. (2012). Activation of an IL6 inflammatory loop mediates trastuzumab resistance in HER2+ breast cancer by expanding the cancer stem cell population. Mol. Cell. 47, 570-584. doi: 10.1016/j.molcel.2012.06.014

Kotecha, R., Gondi, V., Ahluwalia, M. S., Brastianos, P. K., and Mehta, M. P. (2018). Recent advances in managing brain metastasis. F1000Res. 7:F1000FacultyRev1772. doi: 10.12688/f1000research.15903.1

Krishna, S., Lowery, F. J., Copeland, A. R., Bahadiroglu, E., Mukherjee, R., Jia, L., et al. (2020). Stem-like CD8 T cells mediate response of adoptive cell immunotherapy against human cancer. Science 370, 1328-1334. doi: 10.1126/ science.abb9847

Kudchadkar, R. R., Lowe, M. C., Khan, M. K., and McBrien, S. M. (2020). Metastatic melanoma. CA Cancer J. Clin. 70, 78-85. doi: 10.3322/caac.21599

Kwon, S., Yoo, K. H., Sym, S. J., and Khang, D. (2019). Mesenchymal stem cell therapy assisted by nanotechnology: a possible combinational treatment for brain tumor and central nerve regeneration. Int. J. Nanomed. 14, 5925-5942. doi: $10.2147 /$ IJN.S217923

Lah, T. T., Novak, M., and Breznik, B. (2020). Brain malignancies: Glioblastoma and brain metastases. Semin. Cancer Biol. 60, 262-273. doi: 10.1016/j. semcancer.2019.10.010

Langen, U. H., Ayloo, S., and Gu, C. (2019). Development and cell biology of the blood-brain barrier. Annu. Rev. Cell Dev. Biol. 35, 591-613. doi: 10.1146/ annurev-cellbio-100617-062608

Le Rhun, E., Preusser, M., Roth, P., Reardon, D. A., van den Bent, M., Wen, P., et al. (2019). Molecular targeted therapy of glioblastoma. Cancer Treat. Rev. 80:101896. doi: 10.1016/j.ctrv.2019.101896

Lee, H. S., Han, J., Bai, H. J., and Kim, K. W. (2009). Brain angiogenesis in developmental and pathological processes: regulation, molecular and cellular communication at the neurovascular interface. FEBS J. 276, 4622-4635. doi: 10.1111/j.1742-4658.2009.07174.x

Lee, J. S., Murphy, W. K., Glisson, B. S., Dhingra, H. M., Holoye, P. Y., and Hong, W. K. (1989). Primary chemotherapy of brain metastasis in small-cell lung cancer. J. Clin. Oncol. 7, 916-922. doi: 10.1200/JCO.1989.7.7.916

Lei, Q., Gu, H., Li, L., Wu, T., Xie, W., Li, M., et al. (2020). TNIP1-mediated TNF$\alpha / \mathrm{NF}-\kappa \mathrm{B}$ signalling cascade sustains glioma cell proliferation. J. Cell Mol. Med. 24, 530-538. doi: 10.1111/jcmm.14760

Li, C., Zhao, H., and Wang, B. (2021). Mesenchymal stem/stromal cells: Developmental origin, tumorigenesis and translational cancer therapeutics. Transl Oncol. 14:100948. doi: 10.1016/j.tranon.2020.100948

Li, G. C., Zhang, H. W., Zhao, Q. C., Sun, L., Yang, J. J., Hong, L., et al. (2016). Mesenchymal stem cells promote tumor angiogenesis via the action of transforming growth factor $\beta 1$. Oncol. Lett. 11, 1089-1094. doi: 10.3892/ol.2015. 3997

Li, S., Xu, H. X., Wu, C. T., Wang, W. Q., Jin, W., Gao, H. L., et al. (2019). Angiogenesis in pancreatic cancer: current research status and clinical implications. Angiogenesis 22, 15-36. doi: 10.1007/s10456-018-9645-2

Li, Y., Shi, Y., McCaw, L., Li, Y. J., Zhu, F., Gorczynski, R., et al. (2015). Microenvironmental interleukin-6 suppresses toll-like receptor signaling in human leukemia cells through miR-17/19A. Blood 126, 766-778. doi: 10.1182/ blood-2014-12-618678

Li, Y. D., Lamano, J. B., Lamano, J. B., Quaggin-Smith, J., Veliceasa, D., Kaur, G., et al. (2019). Tumor-induced peripheral immunosuppression promotes brain metastasis in patients with non-small cell lung cancer. Cancer Immunol. Immunother. 68, 1501-1513. doi: 10.1007/s00262-019-02384-y

Liebner, S., Corada, M., Bangsow, T., Babbage, J., Taddei, A., Czupalla, C. J., et al. (2008). Wnt/beta-catenin signaling controls development of the blood-brain barrier. J. Cell Biol. 183, 409-417. doi: 10.1083/jcb.200806024

Liebner, S., Dijkhuizen, R. M., Reiss, Y., Plate, K. H., Agalliu, D., and Constantin, G. (2018). Functional morphology of the blood-brain barrier in health and disease. Acta Neuropathol. 135, 311-336. doi: 10.1007/s00401-018-1815-1

Liebner, S., Fischmann, A., Rascher, G., Duffner, F., Grote, E. H., Kalbacher, H., et al. (2000). Claudin-1 and claudin-5 expression and tight junction morphology are altered in blood vessels of human glioblastoma multiforme. Acta. Neuropathol. 100, 323-331. doi: 10.1007/s004010000180 
Liman, T. G., and Endres, M. (2012). New vessels after stroke: postischemic neovascularization and regeneration. Cerebrovasc. Dis. 33, 492-499. doi: 10. $1159 / 000337155$

Lin, N. U., Borges, V., Anders, C., Murthy, R. K., Paplomata, E., Hamilton, E., et al. (2020). Intracranial efficacy and survival with tucatinib plus trastuzumab and capecitabine for previously treated HER2-positive breast cancer with brain metastases in the HER2CLIMB trial. J. Clin. Oncol. 38, 2610-2619. doi: 10.1200/ JCO.20.00775

Lin, R., Li, M., Luo, M., Teng, T., Pan, Y., and Huang, H. (2019). Mesenchymal stem cells decrease blood-brain barrier permeability in rats with severe acute pancreatitis. Cell Mol. Biol. Lett. 24:43. doi: 10.1186/s11658-019-01 67-8

López-Lázaro, M. (2018). The stem cell division theory of cancer. Crit. Rev. Oncol. Hematol. 123, 95-113. doi: 10.1016/j.critrevonc.2018.01.010

Lugano, R., Ramachandran, M., and Dimberg, A. (2020). Tumor angiogenesis: Causes, consequences, challenges and opportunities. Cell Mol. Life Sci. 77, 1745-1770. doi: 10.1007/s00018-019-03351-7

Luo, J., Ok Lee, S., Liang, L., Huang, C. K., Li, L., Wen, S., et al. (2014). Infiltrating bone marrow mesenchymal stem cells increase prostate cancer stem cell population and metastatic ability via secreting cytokines to suppress androgen receptor signaling. Oncogene 33, 2768-2778. doi: 10.1038/onc.2013.233

Lv, W. L., Hu, Y. Y., Li, Z. N., Zhang, W., and Pan, Q. (2020). PAX3 silencing suppresses gastric cancer proliferation and angiogenesis via MET/PI3K signaling. Neoplasma 67, 304-311. doi: 10.4149/neo_2019_190429N378

Lytle, N. K., Barber, A. G., and Reya, T. (2021). Stem cell fate in cancer growth, progression and therapy resistance. Nat. Rev. Cancer 18, 669-680. doi: 10.1038/ s41568-018-0056-x

Ma, L., Hernandez, M. O., Zhao, Y., Mehta, M., Tran, B., Kelly, M., et al. (2019). Tumor cell biodiversity drives microenvironmental reprogramming in liver cancer. Cancer Cell. 36, 418-430. doi: 10.1016/j.ccell.2019.08.007

Menge, T., Zhao, Y., Zhao, J., Wataha, K., Gerber, M., Zhang, J., et al. (2012). Mesenchymal stem cells regulate blood-brain barrier integrity through TIMP3 release after traumatic brain injury. Sci. Transl. Med. 4:161ra150. doi: 10.1126/ scitranslmed. 3004660

Metz, M. Z., Gutova, M., Lacey, S. F., Abramyants, Y., Vo, T., Gilchrist, M., et al. (2013). Neural stem cell-mediated delivery of irinotecan-activating carboxylesterases to glioma: implications for clinical use. Stem Cells Transl. Med. 2, 983-992. doi: 10.5966/sctm.2012-0177

Miloradovic, D., Miloradovic, D., Markovic, B. S., Acovic, A., Harrell, C. R., Djonov, V., et al. (2020). The effects of mesenchymal stem cells on antimelanoma immunity depend on the timing of their administration. Stem Cells Int. 2020, 1-13. doi: 10.1155/2020/8842659

Molotkov, A., Carberry, P., Dolan, M. A., Joseph, S., Idumonyi, S., Oya, S., et al. (2021). Real-time positron emission tomography evaluation of topotecan brain kinetics after ultrasound-mediated blood-brain barrier permeability. Pharmaceutics 13:405. doi: 10.3390/pharmaceutics13030405

Mooney, R., Abidi, W., Batalla-Covello, J., Ngai, H. W., Hyde, C., Machado, D., et al. (2021). Allogeneic human neural stem cells for improved therapeutic delivery to peritoneal ovarian cancer. Stem Cell Res. Ther. 12:205. doi: 10.1186/ s13287-021-02226-8

Motzer, R. J., Craig, J., Nichols, K. A., Margolin, J. B., Paul, G. R., Nicholas, J., et al. (2007). Phase III randomized trial of conventional-dose chemotherapy with or without high-dose chemotherapy and autologous hematopoietic stemcell rescue as first-line treatment for patients with poor-prognosis metastatic germ cell tumors. J. Clin. Oncol. 25, 247-256.

Myers, S. E., Mick, R., and Williams, S. F. (1994). High-dose chemotherapy with autologous stem cell rescue in women with metastatic breast cancer with involved bone marrow: a role for peripheral blood progenitor transplant. Bone Marrow Transplant. 13, 449-454

Namouni, F., Doz, F., Tanguy, M. L., Quintana, E., Michon, J., Pacquement, H., et al. (1997). High-dose chemotherapy with carboplatin, etoposide and cyclophosphamide followed by a haematopoietic stem cell rescue in patients with high-risk retinoblastoma: a SFOP and SFGM study. Eur. J. Cancer 33, 2368-2375.

Ngoi, N. Y. L., Eu, J. Q., Hirpara, J., Wang, L., Lim, J. S. J., Lee, S. C., et al. (2020). Targeting cell metabolism as cancer therapy. Antioxid. Redox Signal. 32, 285-308. doi: 10.1089/ars.2019.7947
Nguyen, Q. L., Okuno, N., Hamashima, T., Dang, S. T., Fujikawa, M., Ishii, Y., et al. (2021). Vascular PDGFR-alpha protects against BBB dysfunction after stroke in mice. Angiogenesis 24, 35-46. doi: 10.1007/s10456-020-09742-w

Ni, J., Miao, T., Su, M., Khan, N. U., Ju, X., Chen, H., et al. (2021). PSMAtargeted nanoparticles for specific penetration of blood-brain tumor barrier and combined therapy of brain metastases. J. Control Release 329, 934-947. doi: 10.1016/j.jconrel.2020.10.023

Nih, L. R., Gojgini, S., Carmichael, S. T., and Segura, T. (2018). Dual-function injectable angiogenic biomaterial for the repair of brain tissue following stroke. Nat. Mater. 17:642.

Nisticò, P., Bissell, M., and Radisky, D. (2012). Epithelial-mesenchymal transition: general principles and pathological relevance with special emphasis on the role of matrix metalloproteinases. Cold Spring Harb. Perspect. Biol. 4:a011908. doi: 10.1101/cshperspect.a011908

Osswald, M., Blaes, J., Liao, Y., Solecki, G., Gömmel, M., Berghoff, A. S., et al. (2016). Impact of blood-brain barrier integrity on tumor growth and therapy response in brain metastases. Clin. Cancer Res. 22, 6078-6087. doi: 10.1158/ 1078-0432.CCR-16-1327

Palmieri, D., Chambers, A. F., Felding-Habermann, B., Huang, S., and Steeg, P. S. (2007). The biology of metastasis to a sanctuary site. Clin. Cancer Res. 13, 1656-1662. doi: 10.1158/1078-0432.CCR-06-2659

Papadopoulos, M. C., Saadoun, S., Davies, D. C., and Bell, B. A. (2001). Emerging molecular mechanisms of brain tumour oedema. Br. J. Neurosurg. 15, 101-108. doi: 10.1080/02688690120036775

Park, H. J., Shin, J. Y., Kim, H. N., Oh, S. H., Song, S. K., and Lee, P. H. (2015). Mesenchymal stem cells stabilize the blood-brain barrier through regulation of astrocytes. Stem Cell Res. Ther. 6:187.

Pascucci, L., Coccè, V., Bonomi, A., Ami, D., Ceccarelli, P., Ciusani, E., et al. (2014). Paclitaxel is incorporated by mesenchymal stromal cells and released in exosomes that inhibit in vitro tumor growth: A new approach for drug delivery. J. Control. Release. 192, 262-270. doi: 10.1016/j.jconrel.2014.07.042

Patel, S. P., Kim, K. B., Papadopoulos, N. E., Hwu, W. J., Hwu, P., Prieto, V. G., et al. (2011). A phase II study of gefitinib in patients with metastatic melanoma. Melanoma Res. 21, 357-363. doi: 10.1097/CMR.0b013e3283471073

Pawitan, J. A., Bui, T. A., Mubarok, W., Antarianto, R. D., Nurhayati, R. W., Dilogo, I. H., et al. (2020). Enhancement of the therapeutic capacity of mesenchymal stem cells by genetic modification: A systematic review. Front. Cell Dev. Biol. 8:587776. doi: 10.3389/fcell.2020.587776

Persidsky, Y., Ramirez, S. H., Haorah, J., and Kanmogne, G. D. (2006). Blood-brain barrier: Structural components and function under physiologic and pathologic conditions. J. NeuroImmune Pharmacol. 1, 223-236. doi: 10.1007/s11481-0069025-3

Peruzzaro, S. T., Andrews, M. M. M., Al-Gharaibeh, A., Pupiec, O., Resk, M., Story, D., et al. (2019). Transplantation of mesenchymal stem cells genetically engineered to overexpress interleukin-10 promotes alternative inflammatory response in rat model of traumatic brain injury. J. Neuroinflam. 16, 2-2.

Petrillo, M., Patella, F., Pesapane, F., Suter, M. B., Ierardi, A. M., Angileri, S. A., et al. (2018). Hypoxia and tumor angiogenesis in the era of hepatocellular carcinoma transarterial loco-regional treatments. Future Oncol. 14, 2957-2967. doi: 10.2217/fon-2017-0739

Porfyriou, E., Letsa, S., and Kosmas, C. (2021). Hematopoietic stem cell mobilization strategies to support high-dose chemotherapy: A focus on relapsed/refractory germ cell tumors. World J. Clin. Oncol. 12, 746-766. doi: 10.5306/wjco.v12.i9.746

Priego, N., Zhu, L., Monteiro, C., Mulders, M., Wasilewski, D., Bindeman, W., et al. (2018). STAT3 labels a subpopulation of reactive astrocytes required for brain metastasis. Nat. Med. 24:1481. doi: 10.1038/s41591-018-0108-5

Profaci, C. P., Munji, R. N., Pulido, R. S., and Daneman, R. (2020). The bloodbrain barrier in health and disease: Important unanswered questions. J. Exp. Med. 217:e20190062. doi: 10.1084/jem.20190062

Qian, H., Ding, X., Zhang, J., Mao, F., Sun, Z., Jia, H., et al. (2017). Cancer stemness and metastatic potential of the novel tumor cell line K3: an inner mutated cell of bone marrow-derived mesenchymal stem cells. Oncotarget 8, 39522-39533. doi: 10.18632/oncotarget.17133

Rady, D., Abbass, M. M. S., El-Rashidy, A. A., El Moshy, S., Radwan, I. A., Dörfer, C. E., et al. (2020). Mesenchymal stem/progenitor cells: The prospect of human clinical translation. Stem Cells Int. 2020, 1-46. doi: 10.1155/2020/8837654 
Rahma, O. E., and Hodi, F. S. (2019). The intersection between tumor angiogenesis and immune suppression. Clin. Cancer Res. 25, 5449-5457. doi: 10.1158/10780432.CCR-18-1543

Rambow, F., Rogiers, A., Marin-Bejar, O., Aibar, S., Femel, J., Dewaele, M., et al. (2018). Toward minimal residual disease-directed therapy in melanoma. Cell 174, 843-855. doi: 10.1016/j.cell.2018.06.025

Ramjiawan, R. R., Griffioen, A. W., Duda, D. G., Ramjiawan, R. R., Griffioen, A. W., and Duda, D. G. (2017). Anti-angiogenesis for cancer revisited: Is there a role for combinations with immunotherapy? Angiogenesis 20, 185-204. doi: 10.1007/s10456-017-9552-y

Rankin, E. B., Nam, J. M., and Giaccia, A. J. (2016). Hypoxia: Signaling the metastatic cascade. Trends Cancer 2, 295-304. doi: 10.1016/j.trecan.2016.05. 006

Razmkhah, M., Abtahi, S., and Ghaderi, A. (2019). Mesenchymal stem cells, immune cells and tumor cells crosstalk: A sinister triangle in the tumor microenvironment. Curr. Stem Cell Res. Ther. 14, 43-51. doi: 10.2174/ 1574888X13666180816114809

Ribatti, D., and Tamma, R. (2019). Hematopoietic growth factors and tumor angiogenesis. Cancer Lett. 440-441, 47-53. doi: 10.1016/j.canlet.2018.10.008

Romero-Trejo, D., Mejía-Rodríguez, R., Sierra-Mondragón, E., Navarrete, A., Pérez-Tapia, M., et al. (2021). The systemic administration of neural stem cells expressing an inducible and soluble form of growth arrest specific 1 inhibits mammary gland tumor growth and the formation of metastases. Cytotherapy 23, 223-235. doi: 10.1016/j.jcyt.2020.09.011

Rosner, D., Nemoto, T., and Lane, W. W. (1986). Chemotherapy induces regression of brain metastases in breast carcinoma. Cancer 58, 832-839. doi: 10.1002/10970142(19860815)58:4<832::aid-cncr2820580404<3.0.co;2-w

Rust, R. (2020). Insights into the dual role of angiogenesis following stroke. J. Cereb Blood Flow Metab. 40, 1167-1171. doi: 10.1177/0271678X20906815

Rust, R., Grönnert, L., Gantner, C., Enzler, A., Mulders, G., and Weber, R. Z. (2019). Nogo-A targeted therapy promotes vascular repair and functional recovery following stroke. Proc. Natl. Acad. Sci. U S A. 116, 14270-14279. doi: 10.1073/ pnas. 1905309116

Saft, M., Gonzales-Portillo, B., Park, Y. J., Cozene, B., Sadanandan, N., Cho, J., et al. (2020). Stem cell repair of the microvascular damage in stroke. Cells 9:9092075. doi: $10.3390 /$ cells 9092075

Saito, M., Schetter, A. J., Mollerup, S., Kohno, T., Skaug, V., Bowman, E. D., et al. (2011). The association of microRNA expression with prognosis and progression in early-stage, non-small cell lung adenocarcinoma: A retrospective analysis of three cohorts. Clin. Cancer Res. 17, 1875-1882. doi: 10.1158/10780432.CCR-10-2961

Salmaninejad, A., Valilou, S. F., Soltani, A., Ahmadi, S., Abarghan, Y. J., Rosengren, R. J., et al. (2019). Tumor-associated macrophages: Role in cancer development and therapeutic implications. Cell Oncol. (Dordr). 42, 591-608. doi: 10.1007/ s13402-019-00453-z

Sansone, P., Storci, G., Tavolari, S., Guarnieri, T., Giovannini, C., Taffurelli, M., et al. (2007). IL-6 triggers malignant features in mammospheres from human ductal breast carcinoma and normal mammary gland. J. Clin. Invest. 117, 3988-4002. doi: 10.1172/JCI32533

Sarkaria, J. N., Hu, L. S., Parney, I. F., Pafundi, D. H., Brinkmann, D. H., Laack, N. N., et al. (2018). Is the blood-brain barrier really disrupted in all glioblastomas? A critical assessment of existing clinical data. Neuro. Oncol. 20, 184-191. doi: 10.1093/neuonc/nox175

Schaaf, M. B., Garg, A. D., and Agostinis, P. (2018). Defining the role of the tumor vasculature in antitumor immunity and immunotherapy. Cell Death Dis. 9:115.

Schadendorf, D., van Akkooi, A., Berking, C., Griewank, K. G., Gutzmer, R. Hauschild, A., et al. (2018). Melanoma. Lancet 392, 971-984. doi: 10.1016/ S0140-6736(18)31559-9

Schetter, A. J., Heegaard, N. H., and Harris, C. C. (2010). Inflammation and cancer: Interweaving microRNA, free radical, cytokine and p53 pathways. Carcinogenesis 31, 37-49. doi: 10.1093/carcin/bgp272

Schito, L. (2019). Hypoxia-dependent angiogenesis and lymphangiogenesis in cancer. Adv. Exp. Med. Biol. 1136, 71-85. doi: 10.1007/978-3-030-127 34-3_5

Schreiber, S., Bueche, C. Z., Garz, C., and Braun, Z. (2013). Blood brain barrier breakdown as the starting point of cerebral small vessel disease? - New insights from a rat model. Exp. Transl. Stroke Med. 5:4.
Schulz, M., Salamero-Boix, A., Niesel, K., Alekseeva, T., and Sevenich, L. (2019). Microenvironmental regulation of tumor progression and therapeutic response in brain metastasis. Front. Immunol. 10:1713. doi: 10.3389/fimmu.2019.01713

Schwartzentruber, D. J., Lawson, D. H., Richards, J. M., Conry, R. M., Miller, D. M., Treisman, J., et al. (2011). gp100 peptide vaccine and interleukin-2 in patients with advanced melanoma. N. Engl. J. Med. 364, 2119-2127. doi: 10.1056/NEJMoa1012863

Segarra, M., Aburto, M. R., and Acker-Palmer, A. (2021). Blood-brain barrier dynamics to maintain brain homeostasis. Trends Neurosci. 44, 393-405. doi: 10.1016/j.tins.2020.12.002

Seol, H. J., Jin, J., Seong, D. H., Joo, K. M., Kang, W., Yang, H., et al. (2011). Genetically engineered human neural stem cells with rabbit carboxyl esterase can target brain metastasis from breast cancer. Cancer Lett. 311, 152-159. doi: 10.1016/j.canlet.2011.07.001

Serakinci, N., and Cagsin, H. (2019). Programming hMSCs into potential genetic therapy in cancer. Crit. Rev. Eukaryot. Gene Expr. 29, 343-350. doi: 10.1615/ CritRevEukaryotGeneExpr.2019030483

Serhal, R., Saliba, N., Hilal, G., Moussa, M., Hassan, G. S., El Atat, O., et al. (2019). Effect of adipose-derived mesenchymal stem cells on hepatocellular carcinoma: In vitro inhibition of carcinogenesis. World J. Gastroenterol. 25, 567-583. doi: 10.3748/wjg.v25.i5.567

Sevenich, L., Bowman, R. L., Mason, S. D., Quail, D. F., Rapaport, F., Elie, B. T., et al. (2014). Analysis of tumour- and stroma-supplied proteolytic networks reveals a brain-metastasis-promoting role for cathepsin S. Nat. Cell Biol. 16, 876-888. doi: $10.1038 /$ ncb3011

Shimoni, A., and Körbling, M. (2002). Tumor cell contamination in re-infused stem cell autografts: does it have clinical significance? Elsevier 41, 241-250. doi: 10.1016/s1040-8428(01)00160-3

Silva, A. Y. O., Amorim, ÉA., Barbosa-Silva, M. C., Lima, M. N., Oliveira, H. A., Granja, M. G., et al. (2020). Mesenchymal stromal cells protect the blood-brain barrier, reduce astrogliosis, and prevent cognitive and behavioral alterations in surviving septic mice. Crit Care Med. 48, e290-e298.

Simard, J. L., Smith, M., and Chandra, S. (2018). Pseudoprogression of melanoma brain metastases. Curr. Oncol. Rep. 20:91. doi: 10.1007/s11912-018-0722-x

Simiczyjew, A., Dratkiewicz, E., Mazurkiewicz, J., Ziêtek, M., Matkowski, R., and Nowak, D. (2020). The influence of tumor microenvironment on immune escape of melanoma. Int. J. Mol. Sci. 21:8359. doi: 10.3390/ijms2121 8359

Somlo, G., Doroshow, J. H., Forman, S. J., Leong, L. A., Margolin, K. A., Jr, R. J., et al. (1994). High-dose doxorubicin, etoposide, and cyclophosphamide with stem cell reinfusion in patients with metastatic or high-risk primary breast cancer. City of hope bone marrow oncology team. Cancer 73, 1678-1685. doi: 10.1002/1097-0142(19940315)73:6<1678::aid-cncr2820730621<3.0.co;2-u

Sprowls, S. A., Arsiwala, T. A., Bumgarner, J. R., Shah, N., Lateef, S. S., and Kielkowski, B. N. (2019). Improving CNS delivery to brain metastases by bloodtumor barrier disruption. Trends Cancer 5, 495-505. doi: 10.1016/j.trecan.2019. 06.003

Stadtmauer, E., O'Neill, A., Goldstein, L., Crilley, P., Mangan, K., Ingle, J., et al. (2000). Conventional-dose chemotherapy compared with high-dose chemotherapy plus autologous hematopoietic stem-cell transplantation for metastatic breast cancer. NEJM 342, 1069-1076. doi: 10.1056/NEJM200004133421501

Steenbruggen, T. G., Steggink, L. C., Seynaeve, C. M., van der Hoeven, J. M. J., Hooning, M. J., Jager, A., et al. (2020). High-dose chemotherapy with hematopoietic stem cell transplant in patients with high-risk breast cancer and 4 or more involved axillary lymph nodes: 20 -year follow-up of a phase 3 randomized clinical trial. JAMA Oncol. 6, 528-534. doi: 10.1001/jamaoncol. 2019.6276

Studeny, M., Marini, F. C., Champlin, R. E., Zompetta, C., Fidler, I. J., and Andreeff, M. (2002). Bone marrow-derived mesenchymal stem cells as vehicles for interferon-beta delivery into tumors. Cancer Res. 62, 3603-3608.

Sweeney, M. D., Zhao, Z., Montagne, A., Nelson, A. R., and Zlokovic, B. V. (2019). Blood-brain barrier: from physiology to disease and back. Physiol. Rev. 99, 21-78. doi: 10.1152/physrev.00050.2017

Tam, S. J., Richmond, D. L., Kaminker, J. S., Modrusan, Z., Martin-McNulty, B., Cao, T. C., et al. (2012). Death receptors DR6 and TROY regulate brain vascular development. Dev. Cell. 22, 403-417. 
Tang, J., Kang, Y., Huang, L., Wu, L., and Peng, Y. (2020). TIMP1 preserves the blood-brain barrier through interacting with $\mathrm{CD} 63$ /integrin $\beta 1$ complex and regulating downstream FAK/RhoA signaling. Acta. Pharm. Sin. B. 10, 987-1003. doi: 10.1016/j.apsb.2020.02.015

Tasdogan, A., Faubert, B., Ramesh, V., Ubellacker, J. M., Shen, B., Solmonson, A., et al. (2020). Metabolic heterogeneity confers differences in melanoma metastatic potential. Nature 577, 115-120. doi: 10.1038/s41586-019-1847-2

Teleanu, R. I., Chircov, C., Grumezescu, A. M., and Teleanu, D. M. (2019). Tumor angiogenesis and anti-angiogenic strategies for cancer treatment. J. Clin. Med. 9:84. doi: $10.3390 / \mathrm{jcm} 9010084$

Testa, U., Pelosi, E., and Castelli, G. (2020). Endothelial progenitors in the tumor microenvironment. Adv. Exp. Med. Biol. 1263, 85-115. doi: 10.1007/978-3-03044518-8_7

Toyoda, K., Tanaka, K., Nakagawa, S., Thuy, D. H. D., Ujifuku, K., and Kamada, K. (2013). Initial contact of glioblastoma cells with existing normal brain endothelial cells strengthen the barrier function via fibroblast growth factor 2 secretion: A new in vitro blood-brain barrier model. Cell Mol. Neurobiol. 33, 489-501. doi: 10.1007/s10571-013-9913-z

Tran, T. T., Mahajan, A., Chiang, V. L., Goldberg, S. B., Nguyen, D. X., Jilaveanu, L. B., et al. (2019). Perilesional edema in brain metastases: Potential causes and implications for treatment with immune therapy. J. Immunother. Cancer 7:200. doi: 10.1186/s40425-019-0684-z

Tu, T. J., Ma, M. W., Monni, S., Rose, A. E., Yee, H., Darvishian, F., et al. (2011). A high proliferative index of recurrent melanoma is associated with worse survival. Oncology 80, 181-187. doi: 10.1159/000328518

Turner, N., Ware, O., and Bosenberg, M. (2018). Genetics of metastasis: melanoma and other cancers. Clin. Exp. Metastasis. 35, 379-391. doi: 10.1007/s10585-0189893-y

Unterleuthner, D., Neuhold, P., Schwarz, K., Janker, L., Neuditschko, B., Nivarthi, H., et al. (2020). Cancer-associated fibroblast-derived WNT2 increases tumor angiogenesis in colon cancer. Angiogenesis 23, 159-177. doi: 10.1007/s10456019-09688-8

Vakhshiteh, F., Atyabi, F., and Ostad, S. N. (2019). Mesenchymal stem cell exosomes: A two-edged sword in cancer therapy. Internat. J. Nanomed. 14:2847. doi: 10.2147/IJN.S200036

Valiente, M., Ahluwalia, M. S., Boire, A., Brastianos, P. K., Goldberg, S. B., Lee, E. Q., et al. (2018). The evolving landscape of brain metastasis. Trends Cancer 4, 176-196. doi: 10.1016/j.trecan.2018.01.003

VanderWalde, A., Ye, W., Frankel, P., Asuncion, D., Leong, L., Luu, T., et al. (2012). Long-term survival after high-dose chemotherapy followed by peripheral stem cell rescue for high-risk, locally advanced/inflammatory, and metastatic breast cancer. Biol. Blood Marrow Transplant. 18, 1273-1280. doi: 10.1016/j.bbmt. 2012.01.021

Varatharaj, A., and Galea, I. (2017). The blood-brain barrier in systemic inflammation. Brain Behav. Immun. 60, 1-12. doi: 10.1016/j.bbi.2016.03.010

Vaupel, P., Schmidberger, H., and Mayer, A. (2019). The Warburg effect: Essential part of metabolic reprogramming and central contributor to cancer progression. Internat. J. Radiat. Bio. 95, 912-919.

Volarevic, V., Markovic, B. S., Gazdic, M., Volarevic, A., Jovicic, N., Arsenijevic, N., et al. (2018). Ethical and safety issues of stem cell-based therapy. Int. J. Med. Sci. 15, 36-45. doi: 10.7150/ijms.21666

von Loga, K., and Gerlinger, M. (2017). Cancer (r)evolution. Nat. Ecol. Evol. 1, 1051-1052. doi: 10.1038/s41559-017-0252-1

Wang, C., Cao, J., Duan, S., Xu, R., Yu, H., Huo, X., et al. (2020). Effect of MicroRNA-126a-3p on bone marrow mesenchymal stem cells repairing blood-brain barrier and nerve injury after intracerebral hemorrhage. J. Stroke Cerebrovasc. Dis. 29:104748. doi: 10.1016/j.jstrokecerebrovasdis.2020.104748

Wang, C., Fei, Y., Xu, C., Zhao, Y., and Pan, Y. (2015). Bone marrow mesenchymal stem cells ameliorate neurological deficits and blood-brain barrier dysfunction after intracerebral hemorrhage in spontaneously hypertensive rats. Int. J. Clin. Exp. Pathol. 8, 4715-4724.

Wang, J., Lei, K., and Han, F. (2018). Tumor microenvironment: Recent advances in various cancer treatments. Eur. Rev. Med. Pharmacol. Sci. 22, 3855-3864. doi: 10.26355/eurrev_201806_15270

Wang, J. X., Choi, S. Y. C., Niu, X., Kang, N., Xue, H., Killam, J., et al. (2020). Lactic acid and an acidic tumor microenvironment suppress anticancer immunity. Int. J. Mol. Sci. 21:8363. doi: 10.3390/ijms21218363
Watkins, S., Robel, S., Kimbrough, I. F., Robert, S. M., Ellis-Davies, G., and Sontheimer, H. (2014). Disruption of astrocyte-vascular coupling and the blood-brain barrier by invading glioma cells. Nat. Commun. 5:4196. doi: 10 . 1038/ncomms5196

Wei, X., Meel, M. H., Breur, M., Bugiani, M., Hulleman, E., and Phoenix, T. N. (2021). Defining tumor-associated vascular heterogeneity in pediatric highgrade and diffuse midline gliomas. Acta. Neuropathol. Commun. 9:142. doi: 10.1186/s40478-021-01243-1

Wickremesekera, A. C., Brasch, H. D., Lee, V. M., Davis, P. F., Woon, K., Johnson, R., et al. (2019). Expression of cancer stem cell markers in metastatic melanoma to the brain. J. Clin. Neurosci. 60, 112-116. doi: 10.1016/j.jocn.2018.10.068

Willis, C. L., Nolan, C. C., Reith, S. N., Lister, T., Prior, M. J. W., Guerin, C. J., et al. (2004). Focal astrocyte loss is followed by microvascular damage, with subsequent repair of the blood-brain barrier in the apparent absence of direct astrocytic contact. Glia 45, 325-337. doi: 10.1002/glia.10333

Winkler, A., Wrzos, C., Haberl, M., Weil, M. T., Gao, M., Möbius, W., et al. (2021). Blood-brain barrier resealing in neuromyelitis optica occurs independently of astrocyte regeneration. J. Clin. Invest. 31:e141694. doi: 10.1172/JCI141694

Xing, F., Liu, Y., Sharma, S., Wu, K., Chan, M. D., Lo, H. W., et al. (2016). Activation of the c-Met pathway mobilizes an inflammatory network in the brain microenvironment to promote brain metastasis of breast cancer. Cancer Res. 76, 4970-4980. doi: 10.1158/0008-5472.CAN-15-3541

Xiong, X., Sun, Y., Sattiraju, A., Jung, Y., Mintz, A., Hayasaka, S., et al. (2015). Remote spatiotemporally controlled and biologically selective permeabilization of blood-brain barrier. J. Control. Release 217, 113-120. doi: 10.1016/j.jconrel. 2015.08.044

Yalçin, B., Kremer, L. C. M., and van Dalen, E. C. (2015). High-dose chemotherapy and autologous haematopoietic stem cell rescue for children with high-risk neuroblastoma. Cochrane Database Syst. Rev. 10:CD006301.

Yang, J., Ma, K., Zhang, C., Liu, Y., Liang, F., Hu, W., et al. (2020). Burns impair blood-brain barrier and mesenchymal stem cells can reverse the process in mice. Front. Immunol. 11:578879. doi: 10.3389/fimmu.2020.578879

Yang, M., Li, J., Gu, P., and Fan, X. (2020). The application of nanoparticles in cancer immunotherapy: Targeting tumor microenvironment. Bioact. Mater. 6, 1973-1987. doi: 10.1016/j.bioactmat.2020.12.010

Yang, Y., Kimura-Ohba, S., Thompson, J. F., Salayandia, V. M., Cossé, M., Raz, L., et al. (2018). Vascular tight junction disruption and angiogenesis in spontaneously hypertensive rat with neuroinflammatory white matter injury. Neurobiol. Dis. 114, 95-110. doi: 10.1016/j.nbd.2018.02.012

Yang, Y., Thompson, J. F., Taheri, S., Salayandia, V. M., McAvoy, T. A., Hill, J. W., et al. (2013). Early inhibition of MMP activity in ischemic rat brain promotes expression of tight junction proteins and angiogenesis during recovery. J. Cereb. Blood Flow Metab. 33, 1104-1114. doi: 10.1038/jcbfm.2013.56

Yang, Y., and Torbey, M. T. (2020). Angiogenesis and blood-brain barrier permeability in vascular remodeling after stroke. Curr. Neuropharmacol. 18, 1250-1265. doi: 10.2174/1570159X18666200720173316

Yi, M., Jiao, D., Qin, S., Chu, Q., Wu, K., and Li, A. (2019). Synergistic effect of immune checkpoint blockade and anti-angiogenesis in cancer treatment. Mol. Cancer. 18:60. doi: 10.1186/s12943-019-0974-6

Zander, A. R., Schmoor, C., Kröger, N., Krüger, W., Möbus, V., Frickhofen, N., et al. (2018). Randomized trial of high-dose adjuvant chemotherapy with autologous hematopoietic stem-cell support versus standard-dose chemotherapy in breast cancer patients with 10 or more positive lymph nodes: overall survival after 6 years of follow-up. Ann. Oncol. 19, 1082-1089. doi: 10.1016/j.bbmt.2012.01.021

Zanotelli, M. R., and Reinhart-King, C. A. (2018). Mechanical forces in tumor angiogenesis. Adv. Exp. Med. Biol. 1092, 91-112. doi: 10.1007/978-3-31995294-9_6

Zhang, J. H., Badaut, J., Tang, J., Obenaus, A., Hartman, R., and Pearce, W. J. (2012). The vascular neural network-a new paradigm in stroke pathophysiology. Nat. Rev. Neurol. 8, 711-716. doi: 10.1038/nrneurol.2012.210

Zhang, L., Zhang, S., Yao, J., Lowery, F. J., Zhang, Q., Huang, W. C., et al. (2015). Microenvironment-induced PTEN loss by exosomal microRNA primes brain metastasis outgrowth. Nature 527, 100-104. doi: 10.1038/nature15376

Zhang, Q., Xiang, W., Yi, D. Y., Xue, B. Z., Wen, W. W., Abdelmaksoud, A., et al. (2018). Current status and potential challenges of mesenchymal stem cell-based therapy for malignant gliomas. Stem Cell Res. Ther. 9:228. doi: 10.1186/s13287018-0977-z 
Zhang, W., Zhu, L., An, C., Wang, R., Yang, L., Yu, W., et al. (2020). The blood brain barrier in cerebral ischemic injury - Disruption and repair. Brain Hemorrhages $1,34-53$.

Zhang, Z., Chen, G., Cheng, Y., Martinka, M., and Li, G. (2011). Prognostic significance of RUNX3 expression in human melanoma. Cancer 117, 27192727. doi: $10.1002 / \mathrm{cncr} .25838$

Zhou, T., Yuan, Z., Weng, J., Pei, D., Du, X., He, C., et al. (2021). Challenges and advances in clinical applications of mesenchymal stromal cells. J. Hematol. Oncol. 14:24. doi: 10.1186/s13045-021-01037-x

Zhu, K., Xie, V., and Huang, S. (2020). Epigenetic regulation of cancer stem cell and tumorigenesis. Adv. Cancer Res. 148, 1-26. doi: 10.1016/bs.acr.2020.05.001

Conflict of Interest: The authors declare that the research was conducted in the absence of any commercial or financial relationships that could be construed as a potential conflict of interest.
Publisher's Note: All claims expressed in this article are solely those of the authors and do not necessarily represent those of their affiliated organizations, or those of the publisher, the editors and the reviewers. Any product that may be evaluated in this article, or claim that may be made by its manufacturer, is not guaranteed or endorsed by the publisher.

Copyright (c) 2021 Sadanandan, Shear, Brooks, Saft, Cabantan, Kingsbury, Zhang, Anthony, Wang, Salazar, Lezama Toledo, Rivera Monroy, Vega Gonzales-Portillo, Moscatello, Lee and Borlongan. This is an open-access article distributed under the terms of the Creative Commons Attribution License (CC BY). The use, distribution or reproduction in other forums is permitted, provided the original author(s) and the copyright owner(s) are credited and that the original publication in this journal is cited, in accordance with accepted academic practice. No use, distribution or reproduction is permitted which does not comply with these terms. 